\title{
Distribution of calcifying and silicifying phytoplankton in relation to environmental and biogeochemical parameters during the late stages of the 2005 North East Atlantic Spring Bloom
}

\author{
K. Leblanc ${ }^{1}$, C. E. Hare ${ }^{2}$, Y. Feng ${ }^{3}$, G. M. Berg ${ }^{4}$, G. R. DiTullio ${ }^{5}$, A. Neeley ${ }^{6}$, I. Benner ${ }^{7,8}$, C. Sprengel ${ }^{7}$, A. Beck ${ }^{9}$, \\ S. A. Sanudo-Wilhelmy ${ }^{10}$, U. Passow ${ }^{7,12}$, K. Klinck ${ }^{7}$, J. M. Rowe ${ }^{11}$, S. W. Wilhelm ${ }^{13}$, C. W. Brown ${ }^{14}$, and \\ D. A. Hutchins ${ }^{10}$ \\ ${ }^{1}$ Université d'Aix-Marseille; CNRS; LOPB-UMR 6535, Laboratoire d'Océanographie Physique et Biogéochimique; \\ OSU/Centre d'Océanologie de Marseille, UMR 6535, Campus de Luminy Case 901, 163 Avenue de Luminy, \\ 13288 Marseille Cedex 09, France \\ ${ }^{2}$ Woods Hole Group, Inc., 100 Carlson Way, Suite 9, Dover, Delaware, 19901, USA \\ ${ }^{3}$ Laboratory of Marine Ecology and Environmental Science, Institute of Oceanology, Chinese Academy of Sciences, \\ Qingdao 266071, China \\ ${ }^{4}$ Department of Environmental Earth System Science, Stanford University, Stanford, CA 94305, USA \\ ${ }^{5}$ Hollings Marine Laboratory, College of Charleston, Charleston, SC 29412, USA \\ ${ }^{6}$ NASA/SSAI/BWTech 1450 S Rolling Road Halethorpe, MD 21227, USA \\ ${ }^{7}$ Alfred Wegener Institute for Polar and Marine Research, Am Handelshafen 12, 27570 Bremerhaven, Germany \\ ${ }^{8}$ Romberg Tiburon Center for Environmental Studies San Francisco State University 3152 Paradise Drive Tiburon, \\ CA 94920, USA \\ ${ }^{9}$ Max-Planck-Institute for Marine Microbiology, Celsiusstrasse 1, 28359 Bremen, Germany \\ ${ }^{10}$ Department of Biological Sciences, University of Southern California, 3616 Trousdale Parkway, Los Angeles, \\ CA 90089, USA \\ ${ }^{11}$ University of Nebraska, the Department of Biological Sciences, in Lincoln, NE 68583, USA \\ ${ }^{12}$ Marine Science Institute, University California Santa Barbara, CA 93106, USA \\ ${ }^{13}$ Department of Microbiology, University of Tennessee, Knoxville, TN 37996, USA \\ ${ }^{14}$ Center for Satellite Applications and Research, National Oceanographic and Atmospheric Administration, \\ College Park, MD 20740, USA
}

Received: 31 May 2009 - Published in Biogeosciences Discuss.: 19 June 2009

Revised: 23 September 2009 - Accepted: 24 September 2009 - Published: 12 October 2009

\begin{abstract}
The late stage of the North East Atlantic (NEA) spring bloom was investigated during June 2005 along a transect section from 45 to $66^{\circ} \mathrm{N}$ between 15 and $20^{\circ} \mathrm{W}$ in order to characterize the contribution of siliceous and calcareous phytoplankton groups and describe their distribution in relation to environmental factors. We measured several biogeochemical parameters such as nutrients, surface trace metals, algal pigments, biogenic silica (BSi), particulate inorganic carbon (PIC) or calcium carbonate, particulate organic carbon, nitrogen and phosphorus (POC, PON and POP, respectively), as well as transparent exopolymer particles
\end{abstract}

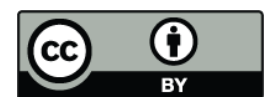

Correspondence to: K. Leblanc (karine.leblanc@univmed.fr)
(TEP). Results were compared with other studies undertaken in this area since the JGOFS NABE program. Characteristics of the spring bloom generally agreed well with the accepted scenario for the development of the autotrophic community. The NEA seasonal diatom bloom was in the late stages when we sampled the area and diatoms were constrained to the northern part of our transect, over the Icelandic Basin (IB) and Icelandic Shelf (IS). Coccolithophores dominated the phytoplankton community, with a large distribution over the Rockall-Hatton Plateau (RHP) and IB. The Porcupine Abyssal Plain (PAP) region at the southern end of our transect was the region with the lowest biomass, as demonstrated by very low Chl $a$ concentrations and a community dominated by picophytoplankton. Early depletion 
of dissolved silicic acid (DSi) and increased stratification of the surface layer most likely triggered the end of the diatom bloom, leading to coccolithophore dominance. The chronic Si deficiency observed in the NEA could be linked to moderate Fe limitation, which increases the efficiency of the $\mathrm{Si}$ pump. TEP closely mirrored the distribution of both biogenic silica at depth and prymnesiophytes in the surface layer suggesting the sedimentation of the diatom bloom in the form of aggregates, but the relative contribution of diatoms and coccolithophores to carbon export in this area still needs to be resolved.

\section{Introduction}

The North Atlantic is an important seasonal sink for atmospheric $\mathrm{CO}_{2}$ through intense convection of cold surface waters and elevated primary productivity during spring (Watson et al., 1991). It also appears to be a large sink for anthropogenic $\mathrm{CO}_{2}$ (Gruber, 1996). The NABE (North Atlantic spring Bloom Experiment) program (1989 and 1990) showed that $\mathrm{CO}_{2}$ variability was strongly related to the phytoplankton bloom dynamics (Ducklow and Harris, 1993).

The spring bloom starts to develop following surface warming and stratification in March-April, and benefits from the large nutrient stocks available following the intense winter convective mixing of surface waters. It propagates northward as surface stratification progresses in what has been described as a rolling green patchwork, strongly riddled by mesoscale and eddy activity (Robinson et al., 1993). A proposed mechanism for the spring bloom in the North East Atlantic (NEA) involves a rapid diatom growth and dominance in the early spring, followed by a more diverse community of prymnesiophytes, cyanobacteria, dinoflagellates and green algae later in the season (Sieracki et al., 1993).

At high latitudes, the NEA is also the site of one of the largest coccolithophore blooms observed anywhere in the ocean. Satellite imagery annually reveals extensive coccolithophore blooms in surface waters between 50 and $63^{\circ} \mathrm{N}$ as well as on the Icelandic shelf (Holligan et al., 1993; Brown and Yoder, 1994; Balch et al., 1996; Iglesias-Rodriguez et al., 2002). It has been hypothesized that the coccolithophore bloom frequently follows the diatom bloom as the growing season progresses. Progressively more stratified surface waters receive stronger irradiances with correspondingly more severe nutrient limitation. Coccolithophores have lower halfsaturation constants for dissolved inorganic nitrogen (DIN) and phosphorus (DIP) compared to diatoms (Eppley et al., 1969; Iglesias-Rodriguez et al., 2002), and their ability to utilize a wide variety of organic nitrogen or phosphorus sources (Benner and Passow, 2009) has been invoked as major factors leading to this succession in surface waters.

Dissolved silicic acid (DSi) availability is also thought to play a major role in phytoplankton community succession.
Recurrent DSi depletion has been observed in the NEA during the NABE (1989) and POMME (2001) programs (Lochte et al., 1993; Sieracki et al., 1993; Leblanc et al., 2005). In these studies during the phytoplankton bloom, DIN stocks were still plentiful while DSi was almost depleted due to diatom uptake in early spring. Thus, the stoichiometry of initially available nutrients following winter deep mixing likely plays a crucial role in the structural development of the spring bloom, which feeds back on the availability of nutrients in the mixed layer (Moutin and Raimbault, 2002).

The partitioning of primary production between calcifiers and silicifiers is of major importance for the efficiency of the biological pump. Both $\mathrm{CaCO}_{3}$ and $\mathrm{SiO}_{2}$ act as ballast minerals, but their differential impact on $\mathrm{C}$ fluxes to depth is still a matter of debate (Boyd and Trull, 2007). The efficiency of the biological pump is also largely a matter of packaging of sinking material, e.g. in faecal pellets or as aggregates with varying transparent exopolymer particles (TEP) contents. TEP are less dense than seawater and consequently higher concentrations of TEP result in decreased sinking velocities (Passow, 2004).

The objectives of the NASB 2005 (North Atlantic Spring Bloom) program was to describe the phytoplankton blooms in the NEA during June 2005 and identify the relative contribution of the two main phytoplankton groups producing biominerals, namely diatoms and coccolithophores, which are thought to play a major role in carbon export to depth. Their distribution in the mixed layer and the strong latitudinal gradients observed along the $20^{\circ} \mathrm{W}$ meridian from the Azores to Iceland are discussed in relation to nutrient and light availability as well as water column stratification.

Our results are compared and contrasted with previous studies carried out in this sector [BIOTRANS 1988 (Williams and Claustre, 1991), NABE 1989 (Ducklow and Harris, 1993), PRIME 1996 (Savidge and Williams, 2001), POMME 2001 (Mémery et al., 2005), AMT (Aiken and Bale, 2000)] and we discuss whether a clear scenario for the NEA spring/summer bloom can be proposed. Our data set is used to ask several key questions about this biogeochemically critical part of the ocean: are the coccolithophore blooms often indicated by the large calcite patches seen in satellite images a major component of the phytoplankton bloom in the NEA? Which environmental factors can best explain the relative dominance of coccolithophores vs. diatoms in this high latitude environment? What causes recurrent silicic acid depletion in the NEA and what are the potential consequences for phytoplankton composition and carbon export? We addressed these questions by investigating the distribution of the major biogeochemical parameters such as particulate opal, calcite, algal pigments, particulate organic carbon (POC), nitrogen (PON) and phosphorus (POP) as well as TEP concentrations in relation to environmental factors such as light, nutrients and trace metals along a transect near the $20^{\circ} \mathrm{W}$ meridian between the Azores and Iceland. 


\section{Material and methods}

\subsection{Study area}

The NASB 2005 (North Atlantic Spring Bloom) transect was conducted on the R/V Seaward Johnson II in the NEA Ocean between 6 June and 3 July 2005. The cruise track was located between $15^{\circ} \mathrm{W}$ and $25^{\circ} \mathrm{W}$, starting at $45^{\circ} \mathrm{N}$ north of the Azores Islands and ending at $66.5^{\circ} \mathrm{N}$ west of Iceland (Fig. 1a). The South-North transect was initially intended to track the $20^{\circ} \mathrm{W}$ meridian but included several deviations in order to follow real-time satellite information locating major coccolithophore blooms and calcite patches. Ship-board $\mathrm{CO}_{2}$, temperature and nutrient perturbation experiments accompanied the field measurements presented here (companion papers: Feng et al., 2009; Rose et al., 2009; Lee et al., 2009; Benner et al., 2009).

\subsection{Sample collection and analysis}

\subsubsection{Hydrographic data}

CTD casts from the surface to $200 \mathrm{~m}$ depths were performed at 37 stations along the transect to emphasize biogeochemical processes in the surface layer. Physical characteristics of the surface water will be included in a description of the main water masses present in the area. Surface water can greatly influence biological processes and their characteristics help determine the location of fronts, eddies, vertical stratification and hydrological provinces that were crossed. Water samples were collected using $10 \mathrm{~L}$ Niskin bottles on a rosette, mounted with a Seabird 9+ CTD equipped with photosynthetically active radiation (PAR), fluorescence and oxygen detectors. Surface trace metal samples were collected using a surface towed pumped "fish" system (Hutchins et al., 1998). Topographical information and section plots were obtained using ODV software (Schlitzer, R., Ocean Data View, http://odv.awi.de, 2007). The depths of the mixed layer $\left(Z_{m}\right)$ and the nutricline $\left(Z_{n}\right)$ were determined as the depth of the strongest gradient in density and dissolved inorganic nitrogen (DIN) respectively between two measurements between the surface and $200 \mathrm{~m}$. Treated CTD density data averaged every $0.5 \mathrm{~m}$ were used for the calculation of $Z_{m}$, while nutrient data collected at 12 depths on average with Niskin bottles were used to compute $Z_{n}$ over the 0-200 m layer. At the highest concentration gradient identified between to Niskin measurements, $Z_{n}$ was determined as the depth of the upper bottle. The euphotic depth $\left(Z_{e}\right)$ was calculated as the $1 \%$ light level using CTD PAR data averaged every $0.5 \mathrm{~m}$.

\subsubsection{Dissolved nutrients and trace metals}

Concentrations of DIN (nitrate+nitrite), DIP and DSi were determined colorimetrically on whole water samples by standard autoanalyzer techniques (Futura continuous flow analyzer, Alliance Instruments) as soon as the samples were col- lected at each station. Near-surface water samples $(\sim 10 \mathrm{~m}$ depth) for trace metal analysis were collected with a pump system using an all-Teflon diaphragm pump (Bruiser) and PFA Teflon tubing attached to a weighted PVC fish (Hutchins et al., 1998). The tubing was deployed from a boom off the side of the ship outside of the wake, and samples were collected as the ship moved forward into clean water at approximately 5 knots. After flushing the tubing well, a $50 \mathrm{~L}$ polyethylene carboy was filled in a clean van and used for subsampling under HEPA-filtered air (removing particles above $0.3 \mu \mathrm{m}$ diameter). All sampling equipment was exhaustively acid-washed, and trace-metal clean handling techniques were adhered to throughout (Bruland et al., 1979). One-liter samples were filtered though $0.22 \mu \mathrm{m}$ pore size polypropylene Calyx capsule filters into low-density polyethylene bottles, and acidified to $\mathrm{pH}<2$ with ultrapure $\mathrm{HCl}$ after conclusion of the cruise. Dissolved metals were preconcentrated from $250 \mathrm{~mL}$ seawater using APDC/DDDC organic solvent extraction (Bruland et al., 1979). Chloroform extracts were brought to dryness, oxidized with multiple aliquots of concentrated ultrapure $\mathrm{HNO}_{3}$, dried again, and reconstituted with $2 \mathrm{~mL}$ of $1 \mathrm{~N}$ ultrapure $\mathrm{HNO}_{3}$. Samples for particulate and intracellular metals were collected onto $2 \mu \mathrm{m}$ polycarbonate filter membranes held in polypropylene filter sandwiches. For intracellular metals determination, cells retained by the filters were washed with $5 \mathrm{~mL}$ of an oxalate solution to remove surface-adsorbed metals (Tovar-Sanchez et al., 2003), and rinsed with filtered, Chelex-cleaned seawater (Tang and Morel, 2006). Material on the total and intracellular particulate filters was digested at room temperature with $2 \mathrm{~mL}$ ultrapure aqua regia and $50 \mu \mathrm{L} \mathrm{HF}$. Concentrated acids were evaporated to near dryness and reconstituted with $2 \mathrm{~mL}$ of $1 \mathrm{~N}$ ultrapure $\mathrm{HNO}_{3}$. Dissolved and particulate metal extracts were analyzed by direct injection ICP-MS (ThermoFisher Element2) following 10-fold dilution, with indium as an internal standard.

\subsubsection{Particulate matter}

PIC, POC and PON: water samples $(400 \mathrm{~mL})$ were filtered onto precombusted glass fibre filters (Whatman $\mathrm{GF} / \mathrm{F}$ ) and dried at $50^{\circ} \mathrm{C}$. At the laboratory, filters were $\mathrm{HCl}$ fumed for $4 \mathrm{~h}$ in a desiccator, redried in an oven at $60^{\circ} \mathrm{C}$ (Lorrain et al., 2003) and measured on a Carlo Erba Strumentazione Nitrogen Analyzer 1500 to determine POC and PON concentrations. A duplicate of each sample was run directly without fuming to obtain Total Particulate Carbon (TPC). PIC concentrations were calculated from the difference between TPC and POC.

POP: between $750 \mathrm{~mL}$ and $1 \mathrm{~L}$ samples were filtered onto precombusted glass fibre filters (Whatman GF/F) and rinsed with $2 \mathrm{~mL}$ of $0.17 \mathrm{M} \mathrm{Na}_{2} \mathrm{SO}_{4}$. The filters were then placed in $20 \mathrm{~mL}$ precombusted borosilicate scintillation vials with $2 \mathrm{~mL}$ of $17 \mathrm{mM} \mathrm{MnSO}_{4}$. The vials were covered with aluminium foil, dried at $95^{\circ} \mathrm{C}$, and stored in a desiccator until 
A

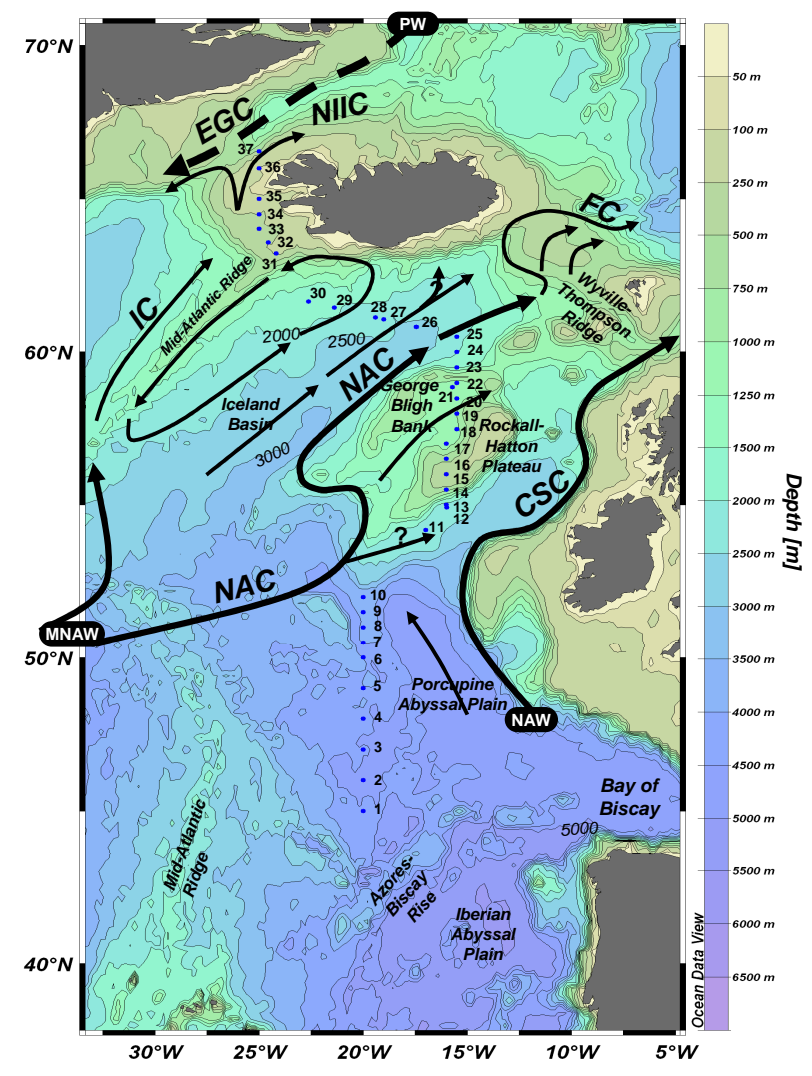

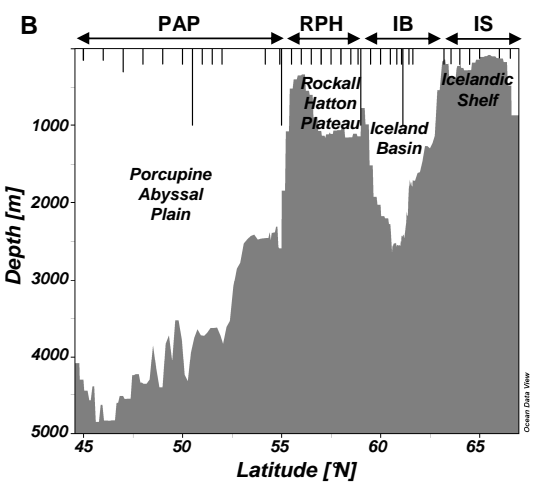

C

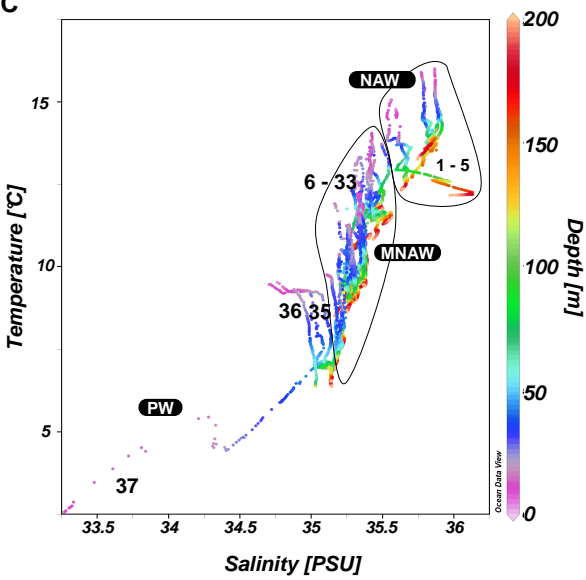

Fig. 1. (A) Map of the study area with stations sampled and main currents theoretical position according to literature. NAW: North Atlantic Waters; MNAW: Modified North Atlantic Waters; NAC: North Atlantic Current; CSC: Continental Slope Current; NIIC: North Icelandic Irminger Current; IC: Irminger Current; EGC: East Greenland Current; FC: Faroe Current. (B) Transect topography plotted using ODV, and depth of the CTDs along the transect. (C) T-S diagram of the water masses between 0 and $200 \mathrm{~m}$ for the 37 stations sampled.

analysis. The vials were combusted at $450^{\circ} \mathrm{C}$ for $2 \mathrm{~h}$, and after cooling $5 \mathrm{~mL}$ of $0.2 \mathrm{~N} \mathrm{HCl}$ were added to each vial for final analysis. Vials were tightly capped and heated at $80^{\circ} \mathrm{C}$ for $30 \mathrm{~min}$ to digest POP into inorganic phosphorus. The digested POP samples were analyzed with the standard molybdate colorimetric method (Solorzano and Sharp, 1980).

BSi (Biogenic Silica): samples for biogenic silica measurements $(1 \mathrm{~L})$ were filtered onto polycarbonate filters $(0.6 \mu \mathrm{m}, 47 \mathrm{~mm})$ and stored in plastic Petri dishes. Filters were dried at $60^{\circ} \mathrm{C}$ for $24 \mathrm{~h}$ and then stored at room temperature. Samples were analyzed for biogenic silica following the digestion of silica in hot $0.2 \mathrm{~N} \mathrm{NaOH}$ for $45 \mathrm{~min}$ (Nelson et al., 1989).

TEP: between $150 \mathrm{~mL}$ (surface) and $400 \mathrm{~mL}$ (at depth) samples were filtered onto $0.4 \mu \mathrm{m}$ polycarbonate filters and directly stained with Alcian blue. Three replicates per depth and six replicate blanks per day were prepared. Stained filters were frozen until analysis or analyzed directly according to Passow and Alldredge (1995). Briefly, filters were soaked in $6 \mathrm{~mL} 80 \% \mathrm{H}_{2} \mathrm{SO}_{4}$. After 2 to $8 \mathrm{~h}$ the absorption of the resulting solution was measured colorimetrically at $787 \mathrm{~nm}$ in a $1 \mathrm{~cm}$ cuvette. Gum Xanthan was used for calibration, thus this method compares the staining capability of TEP to that of Gum Xanthan and values are expressed as Gum Xanthan equivalent per $\mathrm{L}\left(\mu \mathrm{g} \mathrm{Xeq}^{-1}\right)$.

\subsubsection{Taxonomic information}

Pigments: water samples $(1 \mathrm{~L})$ were filtered onto glass fibre filters (Whatman GF/F) and stored in liquid nitrogen until analysis. Samples were analyzed on an Agilent 1100 HPLC (High Performance Liquid Chromatography) system with diode array and fluorescence detection. Elution gradients and protocols were described in detail elsewhere (DiTullio and Geesey, 2002).

Coccolithophore cell counts: water samples of $400 \mathrm{~mL}$ were filtered onto cellulose nitrate filters $(0.45 \mu \mathrm{m}, 47 \mathrm{~mm})$ and dried at $50^{\circ} \mathrm{C}$ for coccolithophore cell counts. Pieces of the filters were sputter-coated with gold-palladium and imaged with a Philips XL-30 digital scanning field-emission electron microscope (SEM). Coccolithophores were counted from SEM images and coccolithophores $\mathrm{L}^{-1}$ were calculated from counts, counting area, filter area and filtered volume. Coccolithophores were only counted at selected depths at 
sites of elevated PIC concentrations (St. 10, 12, 19, 23, 29, $31,33,34)$.

\subsubsection{Satellite images}

Monthly satellite MODIS Chla and calcite composite images were obtained from the Level 3 browser available on the NASA Ocean Biology Processing Group website (http: //oceancolor.gsfc.nasa.gov/).

\subsubsection{Statistical correlation analyses}

A non-parametric two-tailed Spearman Rank correlation coefficient was used as a measure of correlation between the main biogeochemical parameters as the criterion of normal distribution was not met for any of them.

\section{Results}

\subsection{Hydrographic data}

\subsubsection{Topography}

The transect running east of the Mid-Atlantic Ridge, started with stations 1 to 12 located in the Porcupine Abyssal Plain (PAP), one of the deeper regions of the Atlantic Ocean (4000 to $5000 \mathrm{~m}$ ) (Fig. 1a and b). St. 13 to 23 were sampled above the Rockall-Hatton Plateau (RHP), which rises to between 300 and $1200 \mathrm{~m}$. St. 24 to 30 were located above the deep Icelandic Basin (IB) $(3000 \mathrm{~m})$ while the transect ended over the Icelandic shelf (IS) in shallow waters $(<250 \mathrm{~m})$ with St. 31 to 37 .

\subsubsection{Circulation}

The general surface circulation pattern is depicted in Fig. 1a according to Hansen and Østerhus (2000), Otto and Van Aken (1996) and Krauss (1986). Some caution in interpreting these surface currents is necessary, as the direction and flow of the diverse branches of the North Atlantic Current (NAC) are still a matter of debate and show large interannual variability. However, the near surface layers that were sampled during this cruise can be characterized by a mean north-eastward flow in the eastern part of the NA. To the South, the Azores Current (AC) separates in a more southeastwardly drift close to the $45^{\circ} \mathrm{N}$ parallel (Krauss, 1986). The NAC enters the northeastern Atlantic, crossing over the Mid-Atlantic Ridge and is diverted into several branches. The major NAC branch flows northward and is further split into two branches, one crossing the ridge south west of Iceland to become the Irminger Current (IC) and the other flowing through the southern part of the IB over the RHP and towards the Farøes. Part of that second branch can recirculate in a cyclonic gyre over the IB and along the MidAtlantic Ridge. The westernmost Atlantic waters that flow into the Denmark Strait between Iceland and Greenland are usually termed the North Icelandic Irminger Current (NIIC), in probable continuity with the IC. The main NAC carries relatively warm and saline waters from the open North Atlantic to the RHP, and is bounded by a frontal jet between the RHP and the IB. According to Hansen and Østerhus (2000), the NAC flow is probably broad and diffuse while it approaches the RHP and narrows over the slope region. Recirculating flow along the plateau slope is hypothesized, but despite uncertainties about the circulation features above the RHP, the main trajectory of the NAC is north-eastward. NA waters originating from the Armorican Slope off the coast of France are diverted northward following the continental slope and form the Continental Slope Current (CSC).

\subsubsection{Water masses}

From the T-S diagram of the 0-200 m layer (Fig. 1c), St. 1 to 5 show elevated salinity values $(>35.5)$ which could indicate North Atlantic Waters (NAW) originating from the slope rather than the influence of Modified North Atlantic Waters (MNAW), which is usually characterized by lower salinities (St. 6 to 33). Elevated salinity values of the NAW originating from the Armorican Slope may be a result of either mixing with Mediterranean waters or winter cooling, but this is still a matter of debate (Hansen and Østerhus, 2000). As the latitude increases, water masses become progressively fresher and cooler, and the first clear signature of Polar Waters (PW) is seen at the northernmost station (St. 37), with a surface salinity $<33.5$ and surface temperature as low as $2^{\circ} \mathrm{C}$.

\subsubsection{Main hydrological features}

Temperature and salinity profiles overlain with isopycnals are presented in Fig. 2a and b. The southern end of the transect, from St. 1 to 13, was sampled over the PAP and was characterized by warm surface waters $(0-200 \mathrm{~m})$ ranging from 11 to $15^{\circ} \mathrm{C}$ and high salinities (>35.4). A core of highly saline waters $(>36)$ was observed at St. 4 between 150 and $200 \mathrm{~m}$ and may reflect an influence of Mediterranean outflow waters. A first frontal structure was crossed at $55.5^{\circ} \mathrm{N}$ at St. 14 while entering the RHP, as evidenced by a steepening of the $10-11^{\circ} \mathrm{C}$ isotherms and of the 27.2 isopycnal, along the steep shoaling of the bottom isobaths. St. 14 to 23 , located over the RHP, were characterized by colder $\left(<11^{\circ} \mathrm{C}\right)$ water invasions below $50 \mathrm{~m}$. Stations 26 to 30 were sampled over the IB but presented similar vertical profiles to the stations over the RHP. Stations 24 and 25, located above the northern slope of the RHP exhibited a slight upwelling of cooler waters $\left(<11^{\circ} \mathrm{N}\right)$ to the surface. From the circulation scheme proposed in Fig. 1, it can be hypothesized that St. 2425 may be on the main NAC trajectory exiting the RHP. The vertical temperature and density profiles between St. 26 and 30 exhibited an eddy-like structure, with a deepening of the isolines at the centre of this section. 


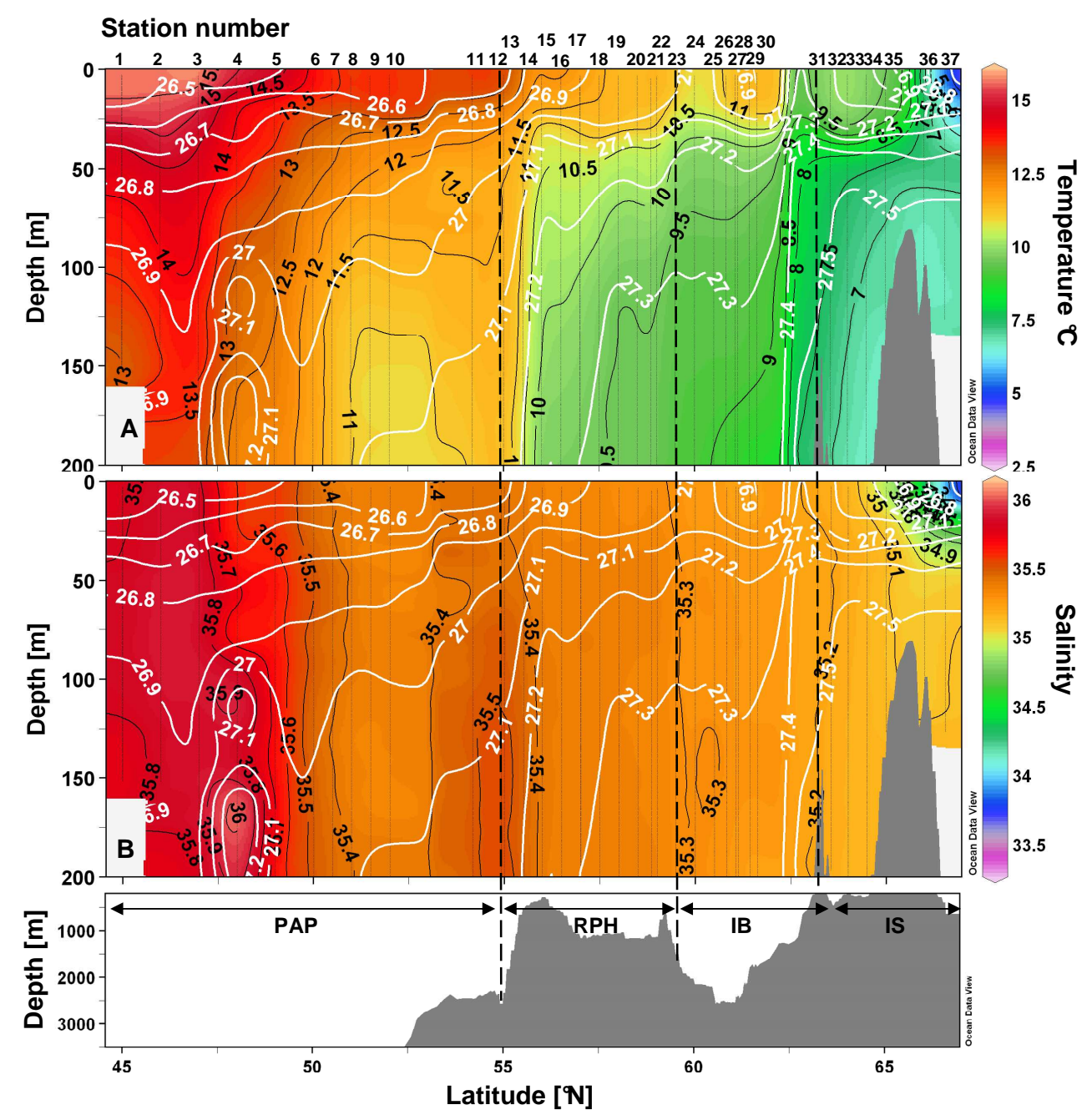

Fig. 2. Vertical sections of temperature $\left({ }^{\circ} \mathrm{C}\right)(\mathbf{A})$ and salinity (B) vs. latitude and bottom topography. The main regions are the Porcupine Abyssal Plain (PAP), the Rockall-Hatton Plateau (RHP), the Icelandic Basin (IB) and Icelandic Shelf (IS).

A second frontal structure was identified between St.30 and $31\left(61.6^{\circ}\right.$ to $\left.63.2^{\circ} \mathrm{N}\right)$, with a sharp deepening of the $9.5^{\circ} \mathrm{C}$ temperature and the 27.4 density isolines. Stations 31 to 37 were located over the IS and the last two stations (36-37) were characterized by a clear influence of colder $\left(2^{\circ} \mathrm{C}\right)$, fresher waters (salinity 34.4$)$ from the retreat of melting sea ice. The water masses encountered between St. 31 and 35 may still be characterized as MNAW according to Hansen and Østerhus (2000), which are defined by temperatures ranging from 7 to $8.5^{\circ} \mathrm{C}$ and salinities between 35.1 and 35.3 over the Greenland-Scotland ridge.

\subsubsection{Mixed layer, euphotic zone and nutricline depth}

The depths of the mixed layer $\left(Z_{m}\right)$, the euphotic layer $\left(Z_{e}\right)$ and the nutricline $\left(Z_{n}\right)$ are presented in Fig. 3. Average $Z_{m}, Z_{e}$ and $Z_{n}$ depths for each region are summarized in Table 1 . The deepest euphotic layers were observed over
Table 1. Mean depths ( \pm standard deviation) of the euphotic zone $\left(Z_{e}\right)$, mixed layer $\left(Z_{m}\right)$ and nutricline $\left(Z_{n}\right)$ in the PAP (Porcupine Abyssal Plain), RHP (Rockall-Hatton Plateau), IB (Icelandic Basin) and IS (Icelandic Shelf) regions.

\begin{tabular}{lrrr}
\hline & $Z_{e}$ & $Z_{m}$ & $Z_{n}$ \\
\hline PAP & $56 \pm 12 \mathrm{~m}$ & $23 \pm 10 \mathrm{~m}$ & $48 \pm 24 \mathrm{~m}$ \\
RHP & $30 \pm 5 \mathrm{~m}$ & $29 \pm 8 \mathrm{~m}$ & $23 \pm 9 \mathrm{~m}$ \\
IB & $28 \pm 9 \mathrm{~m}$ & $30 \pm 9 \mathrm{~m}$ & $20 \pm 10 \mathrm{~m}$ \\
IS & $21 \pm 4 \mathrm{~m}$ & $26 \pm 8 \mathrm{~m}$ & $24 \pm 6 \mathrm{~m}$ \\
\hline
\end{tabular}

the PAP, between 45 and $55^{\circ} \mathrm{N}$, with an average depth of $56 \mathrm{~m}$. $Z_{e}$ depths were shallower in the three northernmost regions (RHP, IB, IS), ranging between 21 and $28 \mathrm{~m}$ on average. There were no significant differences in the $Z_{m}$ depths 


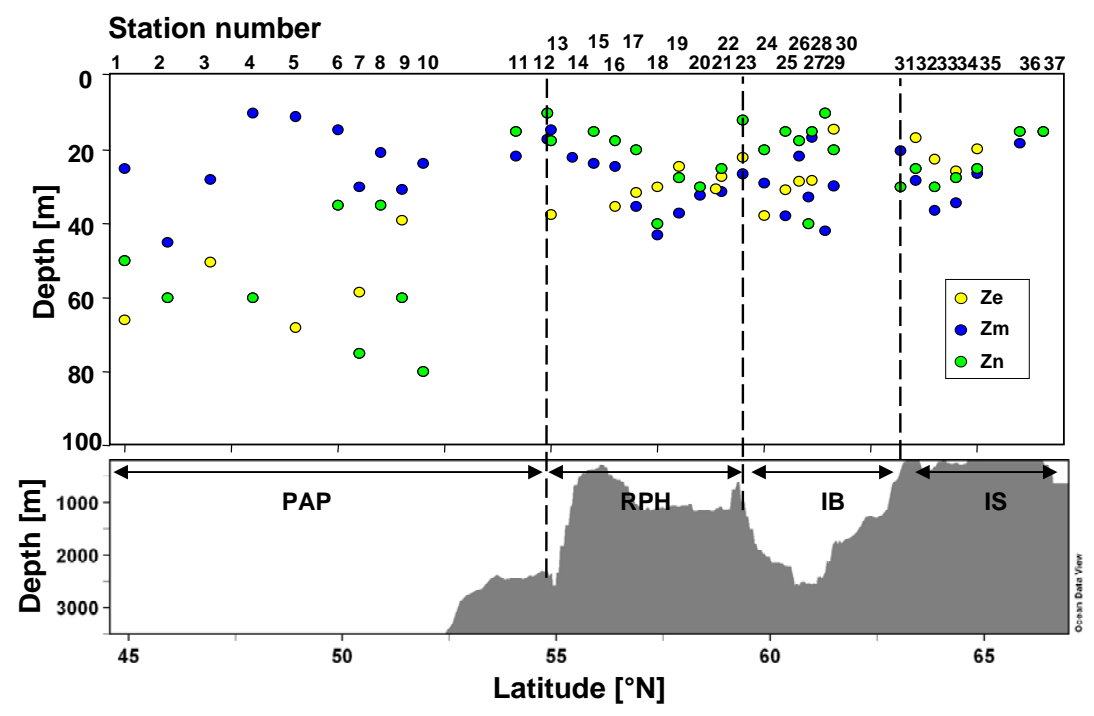

Fig. 3. Depths of the euphotic zone $\left(Z_{e}\right)\left(1 \%\right.$ light level), mixed layer $\left(Z_{m}\right)$ and nitracline $\left(Z_{n}\right)$ vs. latitude and bottom topography.

over the whole transect, with a shallow summer stratification signature observed between 23 and $30 \mathrm{~m}$ for all regions. The depths of the nutricline (calculated from DIN vertical profiles using the trapezoidal integration method between two niskin measurements) were deeper in the PAP region, with an average value of $56 \mathrm{~m}$, but with substantial variability between stations (from 10 to $80 \mathrm{~m}$ ). $Z_{n}$ was shallower in the three northernmost regions, with an average value between 20 and $24 \mathrm{~m}$ and little variability between stations (from 10 to $40 \mathrm{~m}$ ). While $Z_{n}$ depths were calculated from bottle data spaced every 5 to $20 \mathrm{~m}, Z_{m}$ and $Z_{e}$ were calculated from CTD data averaged every $0.5 \mathrm{~m}$. Hence, no significant correlations can be calculated between $Z_{m}$ and $Z_{n}$.

\subsection{Nutrients and trace metal distributions}

\subsubsection{Major nutrients $(\mathrm{Si}, \mathrm{N}, \mathrm{P})$ vertical distribution}

The vertical distributions of DSi, DIN and DIP are presented along the study transect in Fig. 4. For all nutrients, a progressive shoaling of isolines towards the North was observed. The PAP was the most nutrient depleted region in early June, with DSi concentrations in surface waters as low as $0.2 \mu \mathrm{M}$ at $46^{\circ} \mathrm{N}$ (St. 2) and between 50 and $52^{\circ} \mathrm{N}$ (St. 6 to 10). The $1 \mu \mathrm{M}$ isoline was as deep as $100 \mathrm{~m}$ at the southern end of the transect and rose to the surface at both frontal structures, while remaining in the upper $30 \mathrm{~m}$ over the rest of the transect. In general, surface waters were severely Si depleted while there was a constant increase in the deeper water DSi content going from South to North. A similar distribution pattern was observed for DIN and DIP, which were again most depleted in the surface layer in the PAP region and over the IS. DIN concentrations remained between 2 and $4 \mu \mathrm{M}$ in the upper $50 \mathrm{~m}$ in the PAP, but decreased to $1 \mu \mathrm{M}$ at the three northernmost stations west of Iceland in the upper $25 \mathrm{~m}$. DIP levels were below $0.2 \mu \mathrm{M}$ in the mixed layer in the PAP as well as in the IS. Differing from DSi distribution, DIN and DIP were not as severely depleted over the RHP and the IB. All nutrient concentrations increased at the surface at the locations of the two frontal structures at $55^{\circ} \mathrm{N}$ (St. 13) and $63.2^{\circ} \mathrm{N}$ (St. 31) (Fig. 2). Furthermore, a deepening of nutrient concentration isolines observed at $60^{\circ} \mathrm{N}$ over the IS, also seen in the density plots (Fig. 2), may indicate the presence of an anticyclonic eddy.

Nutrient ratios are presented in Fig. 5. The DSi:DIN plot (Fig. 5a) illustrates the severe Si depletion of the $0-200 \mathrm{~m}$ surface layer from $45^{\circ} \mathrm{N}$ to $64.5^{\circ} \mathrm{N}$. DSi:DIN ratios in this region were well below $0.2-0.3$ and close to 0 at several stations $(2,6,7,23$ and 24). In the 100-200 $\mathrm{m}$ layers in the northern part of the transect DSi:DIN ratios were still below 0.4 . DSi only exceeded DIN concentrations at the near surface at two IS stations (St. 35, 37). DIN:DIP ratios were on average close to 15 over the central section of the transect, from $47.5^{\circ}$ to $63^{\circ} \mathrm{N}$, but exhibited higher values at the southern end of the transect (St. 2), with DIN:DIP ratios reaching 43 at $46^{\circ} \mathrm{N}$ (St. 2) in the PAP. DIN:DIP ratios up to 40 were also observed in the upper $50 \mathrm{~m}$ over the IS at $64.5^{\circ} \mathrm{N}$ (St. 34).

\subsubsection{Surface trace metal distribution}

Trace metal concentrations in the dissolved, total particulate and intracellular fractions are shown in Fig. 6, with metal elements ranked in order of increasing average concentrations for the whole transect. In the dissolved fraction, silver $(\mathrm{Ag})$, cobalt $(\mathrm{Co})$ and lead $(\mathrm{Pb})$ were in the picomolar range (Fig. 6a). Cobalt average concentration in surface waters was $28.6 \pm 13.6 \mathrm{pM}$ for the whole transect, but averages for each 


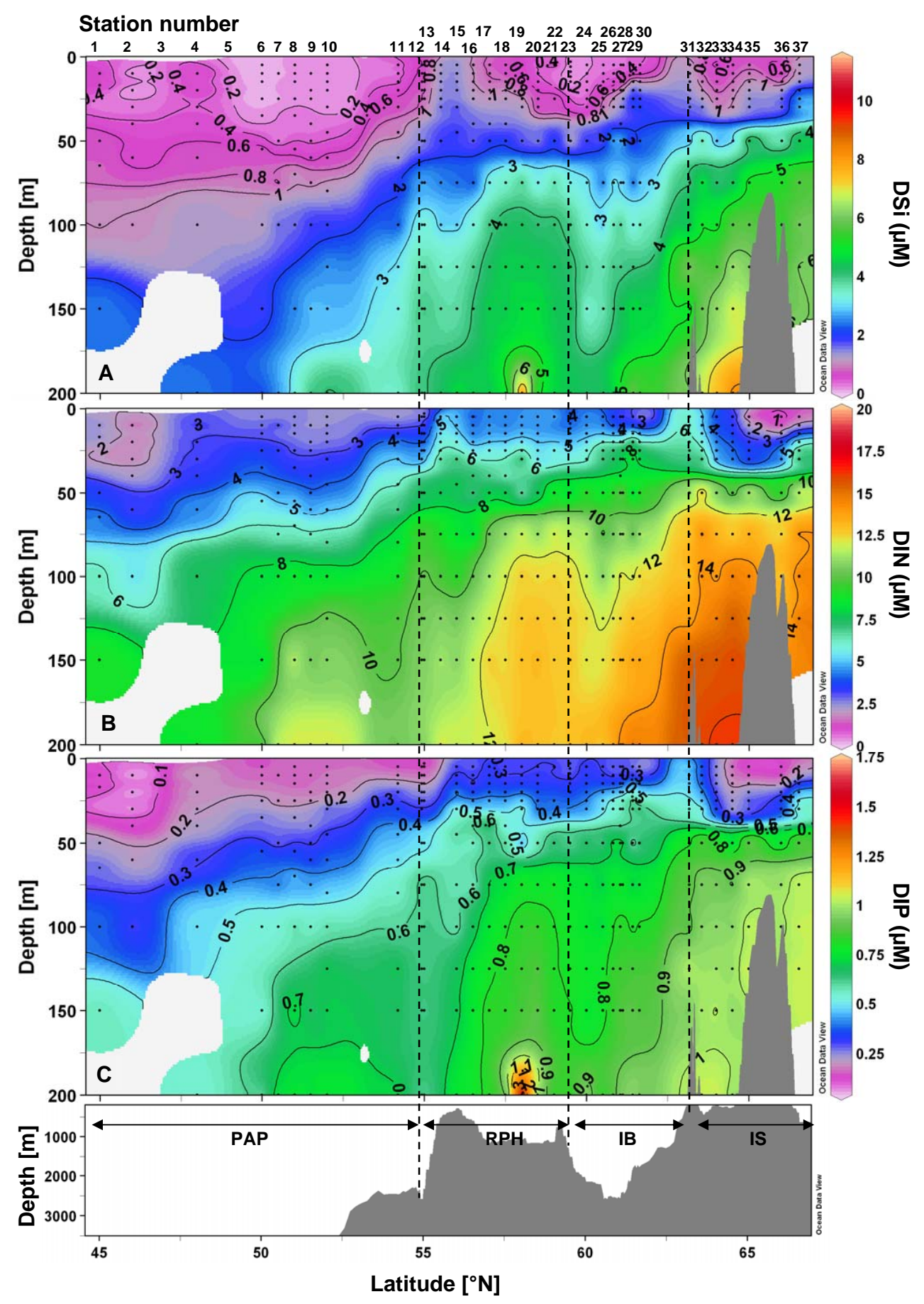

Fig. 4. Vertical sections of (A) Dissolved silicic acid (DSi), (B) Dissolved inorganic nitrogen $\left(\mathrm{NO}_{3}+\mathrm{NO}_{2}\right)(\mathrm{DIN})$ and $(\mathbf{C})$ Dissolved inorganic phosphorus (DIP) in $\mu \mathrm{M}$ vs. latitude and bottom topography.

of the hydrographic regions showed a constant increase from South to North, with the lowest values in the PAP and the highest above the IS. Cadmium $(\mathrm{Cd})$, iron $(\mathrm{Fe})$, zinc $(\mathrm{Zn})$ and copper $(\mathrm{Cu})$ concentrations were fairly similar and in the nanomolar range, with respective average surface concentrations over the transect of $0.7,0.8,1.0$ and $1.1 \mathrm{nM}$. Fe sur- face concentrations were slightly higher over the IS (1.0 nM) and the PAP $(0.8 \mathrm{nM})$, while $\mathrm{Zn}$ concentrations were highest in the PAP $(2.4 \mathrm{nM})$ but were highly variable. Both copper and nickel concentrations were highest in the PAP (1.4 and $5.7 \mathrm{nM}$, respectively). Vanadium (V) and molybdenum (Mo) were the most abundant dissolved metals, with average 


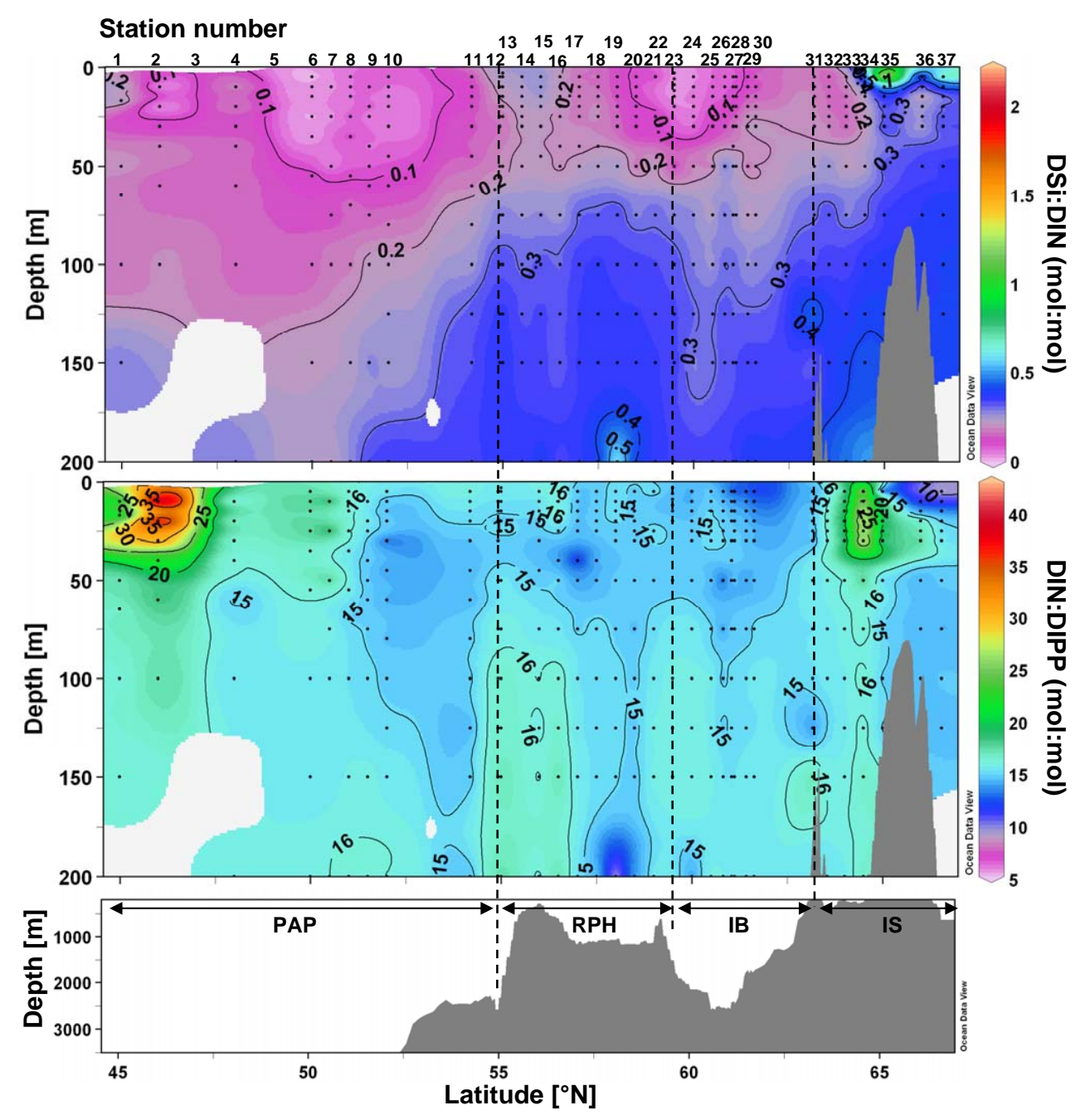

Fig. 5. Vertical sections of (A) Dissolved Si:N ratios (mol:mol), (B) Dissolved N:P ratios (mol:mol) vs. latitude and bottom topography.

concentrations of 25.5 and $123.3 \mathrm{nM}$ respectively and little variability between regions.

Total particulate metal concentrations showed a fairly distinct distribution pattern, with the most abundant elements being $\mathrm{Cu}, \mathrm{Fe}$ and $\mathrm{Zn}$, which were in the nanomolar range (Fig. 6b). Particulate $\mathrm{Cu}$ concentrations were lowest and exhibited low variability from South to North $(0.1 \pm 0.3 \mathrm{nM})$, while particulate $\mathrm{Fe}$ concentrations increased dramatically from South to North, from $0.4 \mathrm{nM}$ in the PAP to $6.2 \mathrm{nM}$ over the IS. Particulate $\mathrm{Zn}$ concentrations were elevated and highly variable $(53.1 \pm 80.1 \mathrm{nM})$ and also increased strongly from the PAP $(5.1 \mathrm{nM})$ to the IB $(109.6 \mathrm{nM})$, but unlike Fe, decreased again over the IS $(51.7 \pm 8.2 \mathrm{nM})$. All other particulate trace metals were in the picomolar range. Some exhibited a steady increase northward similar to $\mathrm{Fe}$ (Mo, Ni and $\mathrm{Mn}$ ), while some increased from the PAP to the IB but decreased again over the IS, similar to $\mathrm{Zn}(\mathrm{Cd}$ and $\mathrm{V})$.
Intracellular metal concentrations for most elements were lower than dissolved or total particulate concentrations and were found in the picomolar range (Fig. 6c). Intracellular $\mathrm{Co}$ and $\mathrm{Cd}$ concentrations were very low $(3.1 \pm 2.7 \mathrm{pM}$ and $8.8 \pm 8.1 \mathrm{pM}$ respectively), while $\mathrm{Cu}$ and $\mathrm{Mn}$ showed a strong increase over the IS with 165.4 and $181.6 \mathrm{pM}$, respectively. Intracellular $\mathrm{Fe}$ and $\mathrm{Zn}$ were the only elements found in the nanomolar range, with overall average concentrations of $1.3 \mathrm{nM}$ and $6.3 \mathrm{nM}$, respectively. Intracellular P from the ICP-MS analyses is indicated as well to show the evolution of biomass over each region, which resembles some trace metals patterns of increase from the PAP to the IB and decrease over the IS. 

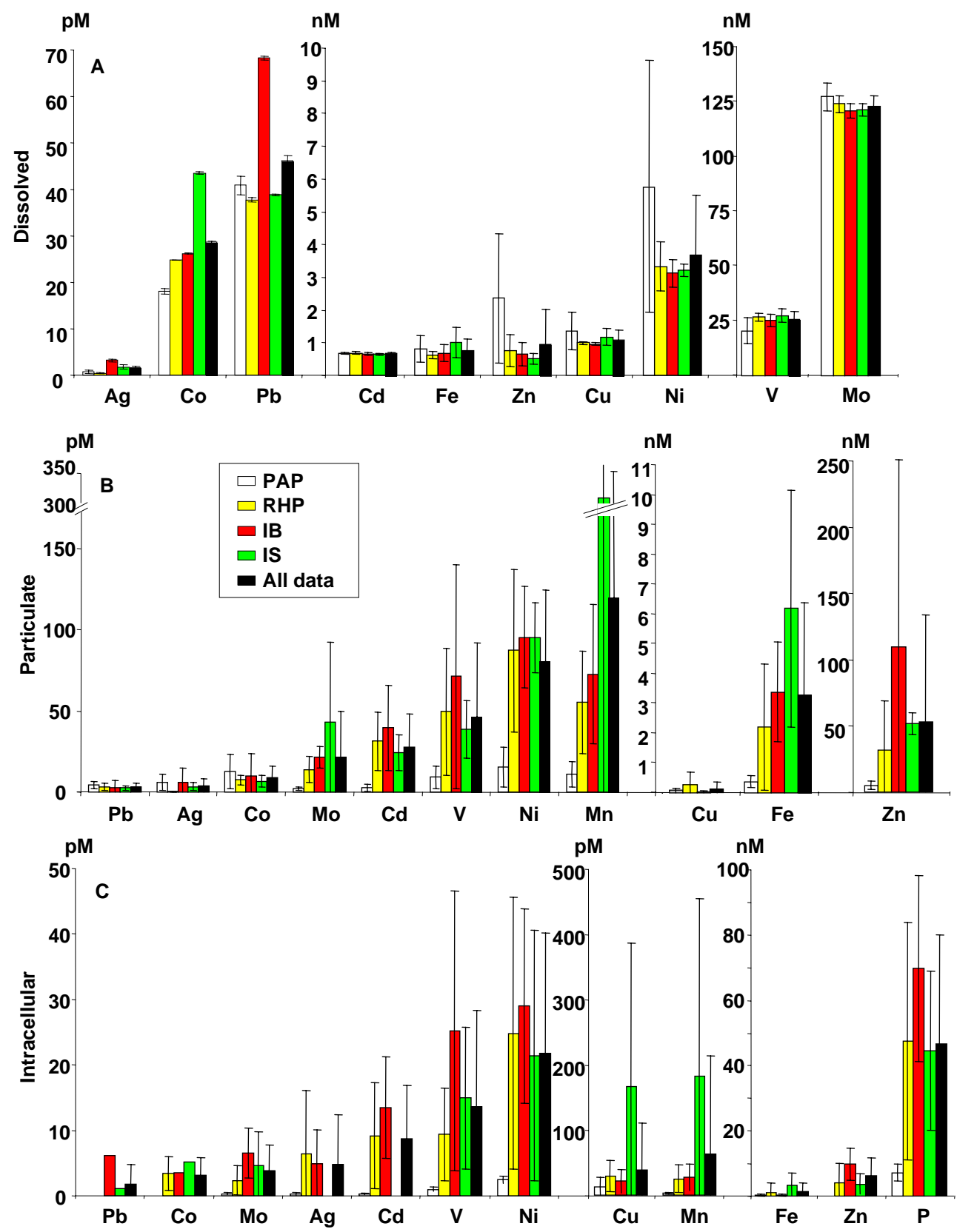

Fig. 6. Surface trace metals concentrations averaged by regions (PAP, RHP, IB and IS) and averaged for the entire data set (All data) and standard deviation (error bars). (A) Dissolved trace metal concentrations, (B) Particulate trace metal concentrations, (C) Intracellular trace metal concentrations.

\subsection{Particulate matter distribution}

\subsubsection{Particulate organic $\mathrm{C}, \mathrm{N}$ and $\mathrm{P}$}

POC and PON were tightly correlated $(r=0.99)$, and the average C:N molar ratio was 5.92 (data not shown), slightly lower than the Redfield ratio (C:N=6.6). PON and POP were less well correlated $(r=0.86)$, but the average $\mathrm{N}: \mathrm{P}$ ratio for all data was 16.05 (data not shown), very close to the Redfield ratio $(\mathrm{N}: \mathrm{P}=16)$. As a general trend, latitudinal transects of POC, PON and POP (Fig. 7a, b, c) revealed a smaller accumulation of biomass in the PAP region and an increase in concentrations northward, with a maximal accumulation of biomass at the surface around $59.5^{\circ} \mathrm{N}$ (St. 23) at the transition between the RHP and IB. Biomass in terms of POC and PON were slightly lower over the IS, while some variability was observed for the POP section with two other concentrations maxima at $50^{\circ} \mathrm{N}$ (St. 6) and $65^{\circ} \mathrm{N}$ (St. 35). 


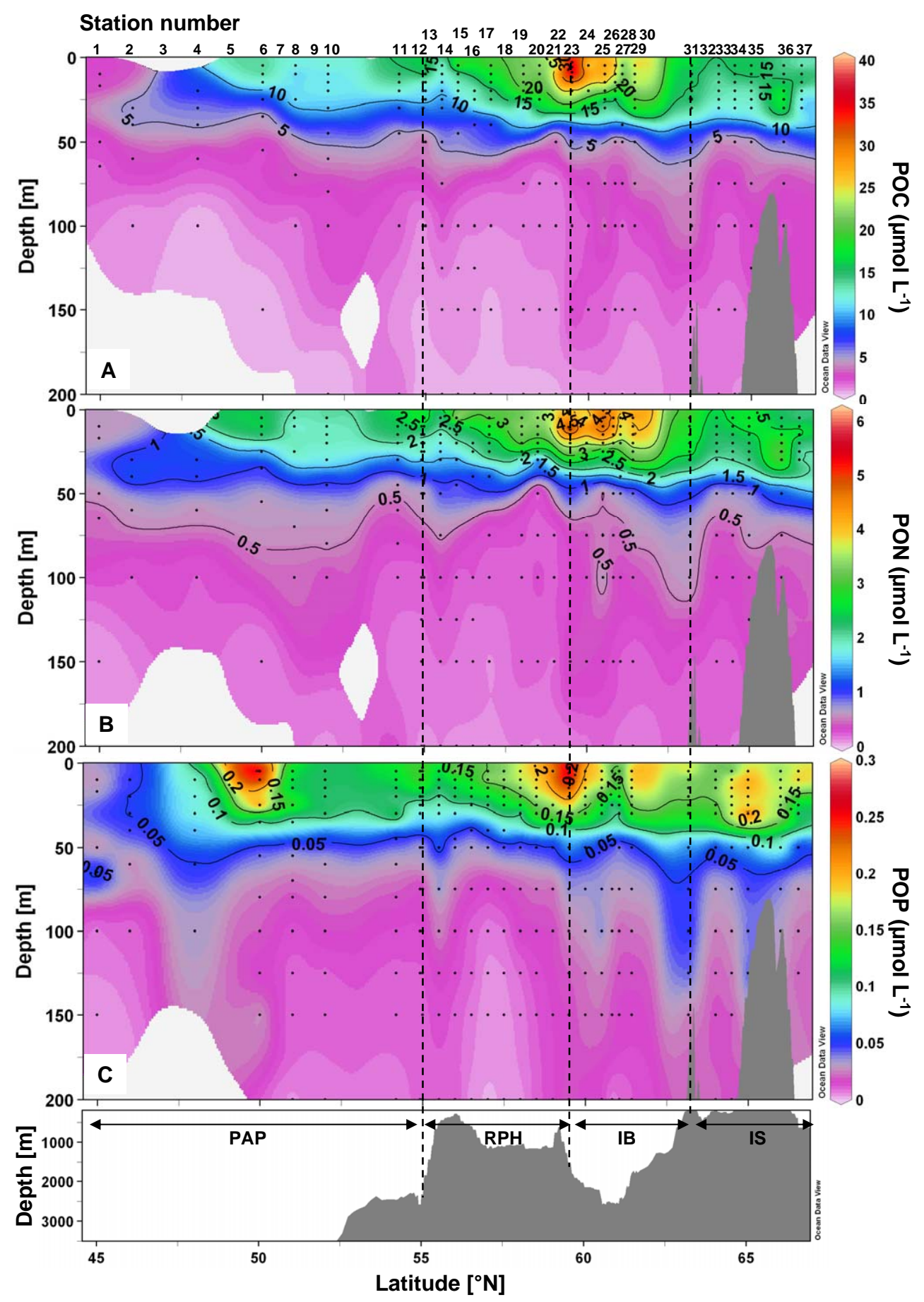

Fig. 7. Vertical sections of (A) Particulate Organic Carbon (POC), (B) Particulate Organic Nitrogen (PON), (C) Particulate Organic Phosphorus (POP) in $\mu \mathrm{mol} \mathrm{L}^{-1}$ vs. latitude and bottom topography.

\subsubsection{Pigment distribution}

The total Chla (TChla), FUCO and HEX, and FUCO:HEX vertical distributions are presented in Fig. 8. The maximum TChl $a$ concentration was observed at the northern end of the transect at $66^{\circ} \mathrm{N}$ over the IS, with $7.4 \mu \mathrm{g} \mathrm{L}-1$ at $25 \mathrm{~m}$
(Fig. 8a). Two smaller TChl $a$ peaks were observed at $63.2^{\circ} \mathrm{N}$ and at $59.5^{\circ} \mathrm{N}$ with 2.8 and $2.6 \mu \mathrm{g} \mathrm{L}^{-1}$, respectively. The distribution of TChla showed a regular increase northward as well as a steady deepening of isolines. The $0.1 \mu \mathrm{g} \mathrm{L}^{-1}$ isoline shoaled at $10 \mathrm{~m}$ between 52.5 and $56^{\circ} \mathrm{N}$, while reaching $50 \mathrm{~m}$ over the IS at $66^{\circ} \mathrm{N}$. 


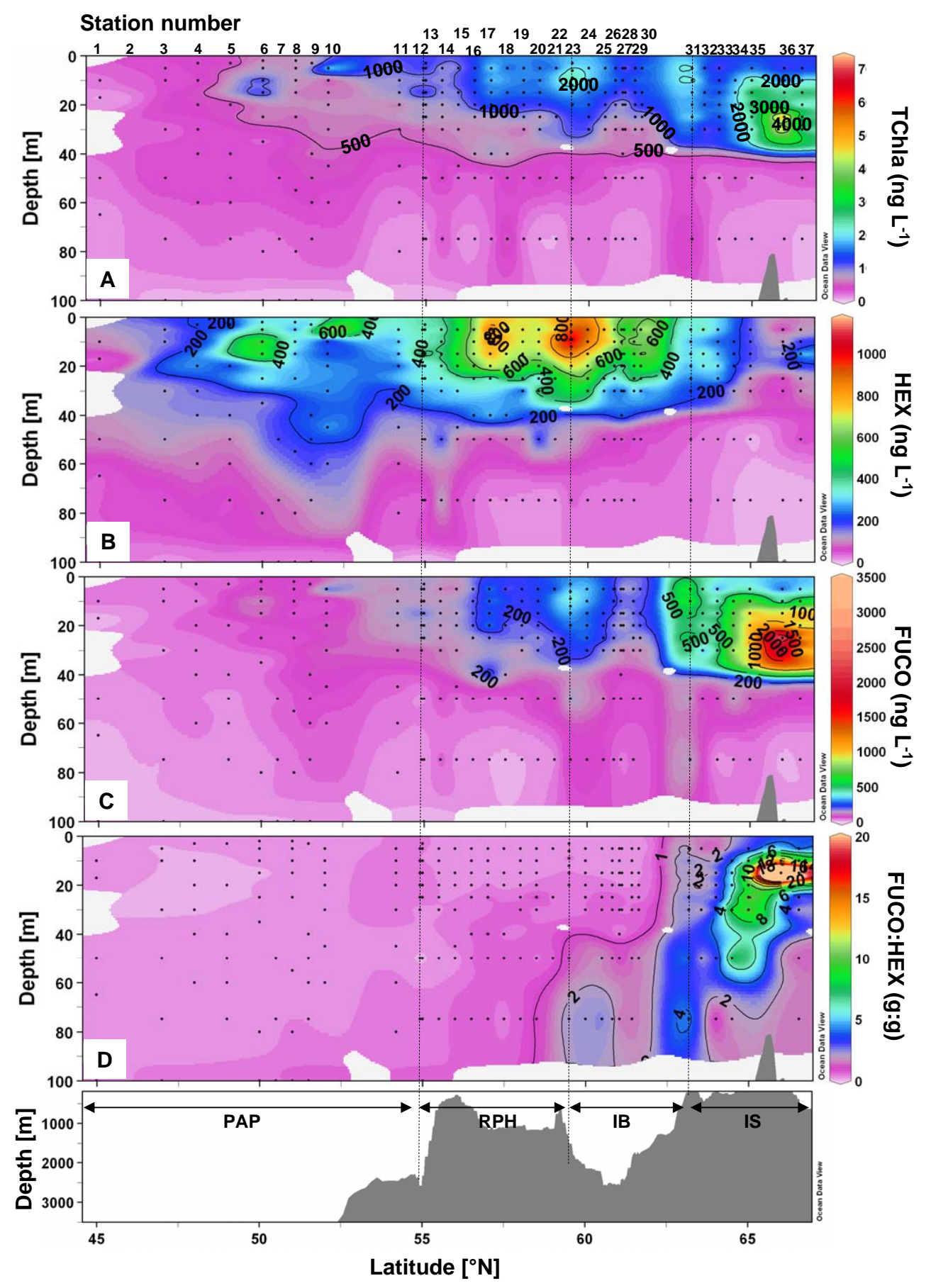

Fig. 8. Vertical sections of (A) Total Chlorophyll $a$ (TChla) in $\mathrm{ng} \mathrm{L}^{-1}$, (B) 19'Hexanoyloxyfucoxanthin (HEX), (C) Fucoxanthin (FUCO) in $\mathrm{n} \mathrm{L}^{-1}$, (D) Fucoxanthin:19'Hexanoyloxyfucoxanthin ratio (FUCO:HEX) (weight:weight) vs. latitude and bottom topography.

The two most abundant pigments measured other than Chl $a$ over the transect were 19'Hexanoyloxyfucoxanthin (HEX) and fucoxanthin (FUCO). Their vertical distributions are represented in Fig. $8 \mathrm{~b}$ and $\mathrm{c}$ and the FUCO:HEX ratio in Fig. 8d. HEX is a diagnostic pigment for prymnesiophytes, including coccolithophores and Phaeocystis spp., both of which were abundant along the transect based on onboard microscopic observations. HEX was the second most abundant pigment measured and was particularly abundant over the RHP and part of the IB, between 55 and $61.6^{\circ} \mathrm{N}$, with a surface maximum value of $1.2 \mu \mathrm{g} \mathrm{L}^{-1}$ located at $59.5^{\circ} \mathrm{N}$, close to the northern edge of the RHP. Two secondary peaks 
were observed in the southern part of the transect over the PAP, at 50 and $52^{\circ} \mathrm{N}$. Fucoxanthin is primarily indicative of diatoms, but can also be synthesized by other chromophytic algal groups (e.g. Phaeocystis pouchetii), dinoflagellates and chrysophytes. The southern part of the transect, from 45 to $56^{\circ} \mathrm{N}$ had particularly low FUCO concentrations (Fig. 10b), which increased slightly over the northern part of the RHP, with concentrations increasing to between 0.1 and $0.5 \mu \mathrm{g} \mathrm{L}{ }^{-1}$. An intense subsurface peak of FUCO was centred above the IS, with maximum values of $3.8 \mu \mathrm{g} \mathrm{L}^{-1}$ at $25 \mathrm{~m}$ at $66^{\circ} \mathrm{N}$, while concentrations at the surface remained low $\left(0.2 \mu \mathrm{g} \mathrm{L}^{-1}\right)$. At $63.2^{\circ} \mathrm{N}$ (St. 31), a secondary peak of FUCO was observed and ranged from 0.5 to $0.7 \mu \mathrm{g} \mathrm{L}^{-1}$ in the upper $30 \mathrm{~m}$. An area of low FUCO concentrations was found over the IB around $61^{\circ} \mathrm{N}$, between the two maxima observed over the RHP and IS. The FUCO:HEX distribution reveals that HEX was the dominant pigment over most of the transect from the PAP to the IB, with ratios $<1$ (Fig. 10c). FUCO represents the major pigment over the IS with a FUCO:HEX ratio as high as 83 at $15 \mathrm{~m}$ at $66^{\circ} \mathrm{N}$ (St. 36). The FUCO:HEX ratio is also $>1$ over the IB below $50 \mathrm{~m}$.

\subsubsection{Distribution of biominerals: $\mathrm{BSi}\left(\mathrm{SiO}_{2}\right)$, PIC $\left(\mathrm{CaCO}_{3}\right)$}

Biominerals representative of siliceous and calcareous phytoplankton are presented in Fig. 9a and b. Particulate Inorganic Carbon (PIC) here indicates the presence of calcareous organisms such as coccolithophores since pteropods were never observed on the filters. The PIC distribution over the transect was very patchy, and except for a region of lower levels over the PAP between 45 and $50^{\circ} \mathrm{N}$, showed no clear trends with latitude (Fig. 9a). The largest accumulation of PIC occurred at the surface at $52^{\circ} \mathrm{N}$ (St. 10), with $11.6 \mu \mathrm{mol} \mathrm{L}^{-1}$. A secondary maximum was observed over the IB, reaching $10.2 \mu \mathrm{mol} \mathrm{L}-1$ at $10 \mathrm{~m}$ depth at $63.2^{\circ} \mathrm{N}$ (St. 31). Comparison between the PIC and HEX peaks located at $52^{\circ} \mathrm{N}$ and $59.5^{\circ} \mathrm{N}$ shows a good agreement, though discrepancies were found over the rest of the transect. A notable peak of PIC at $63.2^{\circ} \mathrm{N}$ (St. 31) was not matched by a HEX increase (Fig. 10). In contrast, there were two large HEX peaks centred at $50^{\circ} \mathrm{N}\left(\right.$ St. 6) and $57^{\circ} \mathrm{N}($ St. 17) that did not correspond to high PIC concentrations (Fig. 9). Hence, the overall correlation between PIC and HEX distributions was poor. The poor correlation between HEX and PIC may be explained by the presence of Phaeocystis pouchetii which was observed in bioassay experiments (data not shown) or by the presence of naked coccolithophores.

Biogenic silica distribution was very different from PIC and showed a marked increase north of $54.2^{\circ} \mathrm{N}$ (St. 11) while the southern part of the transect revealed very low BSi concentrations (Fig. 9b). The first large increase in BSi was observed at 59.5 and $60^{\circ} \mathrm{N}$ (St. 23, 24) with concentrations ranging from 0.75 to $1.27 \mu \mathrm{mol} \mathrm{L}^{-1}$ in the upper $25 \mathrm{~m}$ at these two stations. A deep BSi maximum was also found over the IB at $60.5^{\circ} \mathrm{N}$ (St. 25), with a peak of $1.08 \mu \mathrm{mol} \mathrm{L}{ }^{-1}$ at $100 \mathrm{~m}$, extending to $200 \mathrm{~m}\left(0.45 \mu \mathrm{mol} \mathrm{L}^{-1}\right)$. Low BSi concentrations were again found over part of the IB between 61.04 and $61.43^{\circ} \mathrm{N}$ (St. 27, 29). From $63.2^{\circ} \mathrm{N}$ (St. 31) and northward, BSi was abundant from the surface to at least $200 \mathrm{~m}$ (concentrations below $200 \mathrm{~m}$ not measured). Entering the IS, a large BSi accumulation was found at $63.2^{\circ} \mathrm{N}$ (St. 31) from the surface $\left(0.86 \mu \mathrm{mol} \mathrm{L}^{-1}\right)$ to the bottom of the profile $\left(0.78 \mu \mathrm{mol} \mathrm{L} \mathrm{L}^{-1}\right)$, with a maximum found as deep as $125 \mathrm{~m}\left(1.19 \mu \mathrm{mol} \mathrm{L}^{-1}\right)$. The highest BSi accumulation of the transect was centred above the bathymetrical rise located over the IS, from 65 to $66^{\circ} \mathrm{N}$ (St. 35, 36) and reached a maximum concentration of $1.61 \mu \mathrm{mol} \mathrm{L}^{-1}$ at $25 \mathrm{~m}$ at $66^{\circ} \mathrm{N}$, while the surface concentration at this site was moderate $\left(0.38 \mu \mathrm{mol} \mathrm{L}^{-1}\right)$. At the northernmost station, at $66.55^{\circ} \mathrm{N}$ (St. 37), BSi showed an intense surface peak $\left(1.12 \mu \mathrm{mol} \mathrm{L}^{-1}\right.$ at $\left.15 \mathrm{~m}\right)$, which decreased sharply below $50 \mathrm{~m}\left(<0.16 \mu \mathrm{mol} \mathrm{L}^{-1}\right)$. Overall, the three stations that presented the highest BSi concentrations corresponded to increased FUCO levels (at 59.5-60, 63.2 and $66^{\circ} \mathrm{N}$ ), however, FUCO was constrained within the upper $50 \mathrm{~m}$, while BSi extended much deeper, to at least $200 \mathrm{~m}$, thus correlation was poor in the deeper water column between these two parameters.

\subsubsection{Other taxonomic information}

A few selected stations were analyzed microscopically for coccolithophore composition and abundance based on the localization of the PIC maxima. These results are presented in Fig. 9c. Unfortunately, no information could be derived regarding the two main PIC maxima at 52 and $63.2^{\circ} \mathrm{N}$ (St. 10, 31 ) as the most abundant species could not be clearly identified in scanning electron microscopy (SEM), due to a layer of material obscuring a clear view. The PIC accumulation over the RHP (St. 19, 23) can be attributed mainly to the presence of Emiliania huxleyi which dominated the coccolithophore assemblage numerically, while the PIC accumulation measured over the IS seems to originate from a bloom of Syracosphaera spp. Other species such as Gephyrocapsa spp., Coccolithus pelagicus, Calcidiscus leptoporus and Coronosphaera spp. were also present but in small abundance. Coccolithus pelagicus was only seen north of $58^{\circ} \mathrm{N}$ (St. 19), while Gephyrocapsa spp. was only observed south of $61.43^{\circ} \mathrm{N}$ (St. 29). Emiliana huxleyi was the most evenly distributed species and was observed throughout the transect. Phaeocystis spp. was also observed on board together with coccolithophores during bioassay experiments.

\subsubsection{TEP distribution}

TEP distribution is presented in Fig. 10. TEP concentrations were lowest at the southern end of the transect over the PAP, and started to increase from $50^{\circ} \mathrm{N}$ (St. 5) and northward, with the highest concentrations found at both edges of the IB. 


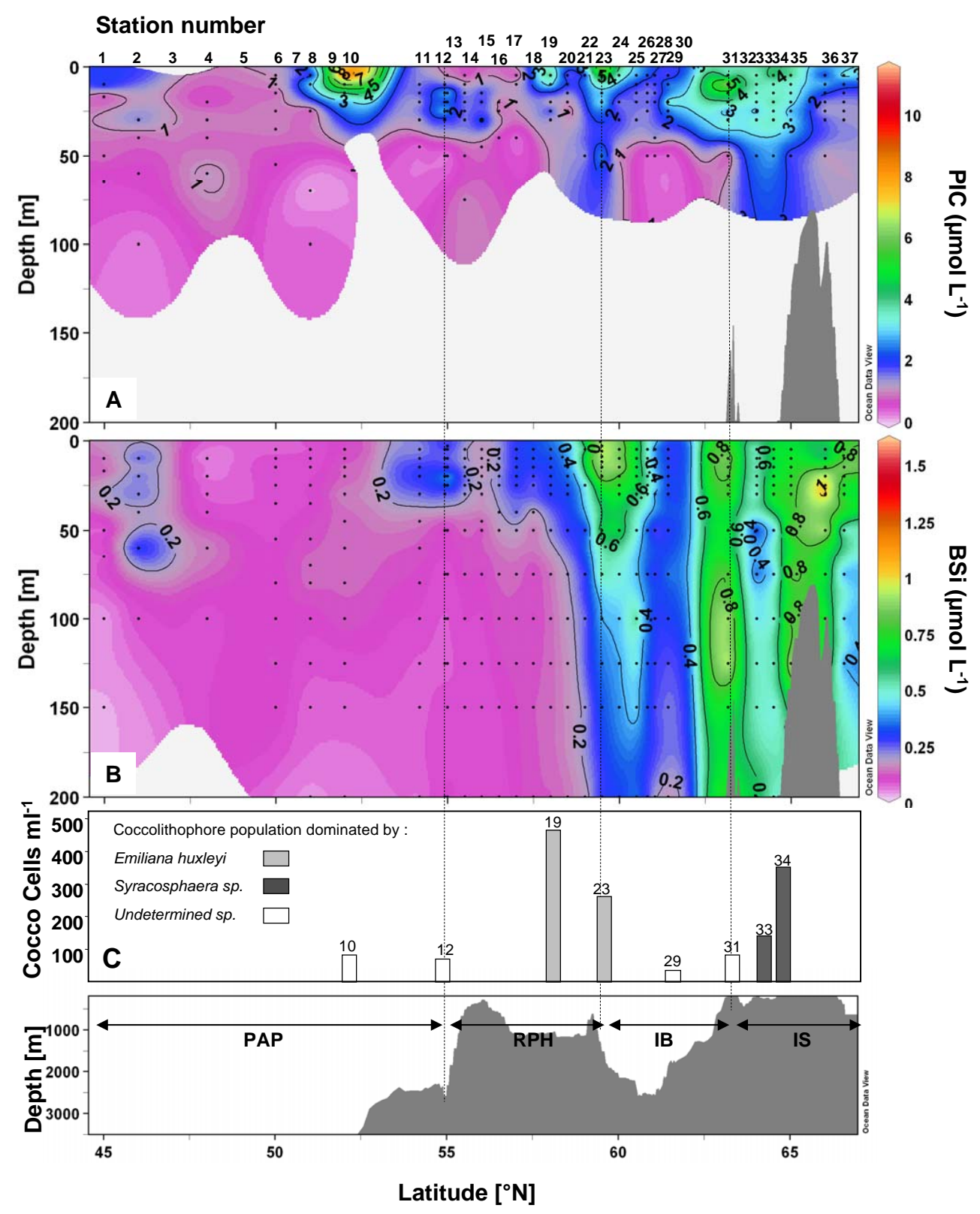

Fig. 9. Vertical sections of (A) Particulate Inorganic Carbon (PIC), (B) Biogenic Silica (BSi) in $\mu$ mol L ${ }^{-1}$, (C) Coccolithophore cell counts (cells $\mathrm{mL}^{-1}$ ) and taxonomic information at selected PIC maxima vs. latitude and bottom topography.

Elevated TEP concentrations were measured at the surface at 55, 59.5 and $63.2^{\circ} \mathrm{N}$ (St. 13, 23, 31), with concentrations ranging between 300 and $420 \mu \mathrm{g} \mathrm{Xeq} \mathrm{L}{ }^{-1}$. TEP were mainly found in the upper $50 \mathrm{~m}$ layer, but extended to $75 \mathrm{~m}$ on two occasions at 60 and $63.2^{\circ} \mathrm{N}$ (St. 24, 31).

\subsection{Integrated data}

Average integrated data of diatom and coccolithophore indicators (BSi, FUCO, PIC, HEX) and of biomass indicators (TChl $a$ and POC) are presented for each provinces in
Fig. 11. We emphasize that HEX, in addition to being a marker of coccolithophore presence, may also indicate the presence of Phaeocystis pouchetii during the NASB bloom. Standard deviation bars are relatively large, highlighting the strong mesoscale variability over the transect. Integrated BSi ranged from 17.7 to $102.2 \mathrm{mmol} \mathrm{m}^{-2}$ and increased steadily from South to North (Fig. 11a). Integrated PIC was very similar in the three southernmost provinces, despite patchy profiles, with values ranging from 67.3 to $78.4 \mathrm{mmol} \mathrm{m}^{-2}$ but nearly doubled over the IS with $135.1 \mathrm{mmol} \mathrm{m}^{-2}$ (Fig. 11a). Integrated FUCO was lowest over the PAP in the south and 


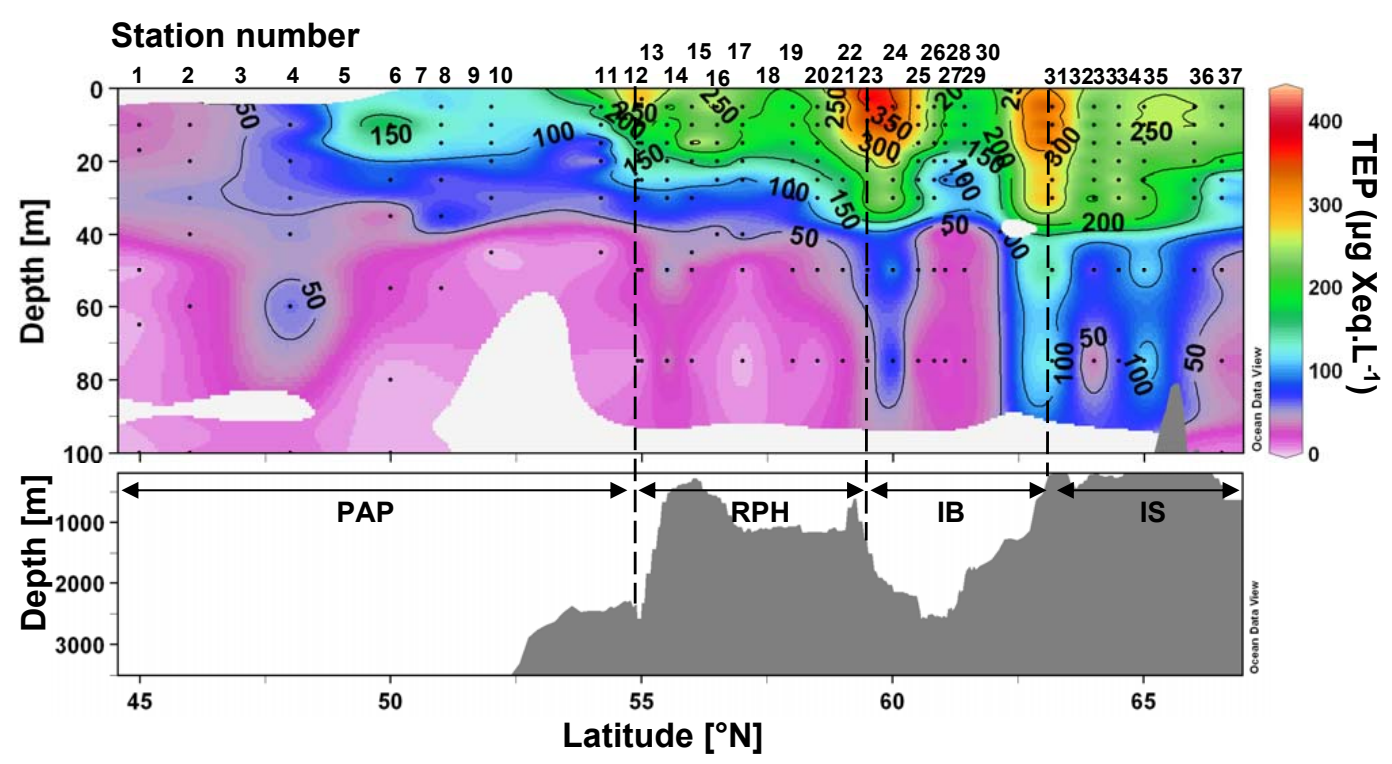

Fig. 10. Vertical section of Transparent Exopolymer Particles (TEP) in Gum Xanthan equivalent per Liter $\left(\mu g\right.$ Xeq $\left.L^{-1}\right)$ vs. latitude and bottom topography.

highest over the IS (from 3.5 to $34.3 \mathrm{mg} \mathrm{m}^{-2}$ ), but was similar over the RHP and IB (Fig. 11b). Integrated HEX values were lowest over the IS $\left(8.2 \mathrm{mg} \mathrm{m}^{-2}\right)$ and highest over the RHP $\left(23.7 \mathrm{mg} \mathrm{m}^{-2}\right)$, showing a different distribution pattern than PIC (Fig. 11b). Finally, integrated TChla showed a similar distribution pattern to FUCO, with lowest values over the PAP $\left(30.7 \mathrm{mg} \mathrm{m}^{-2}\right)$ and highest values over the IS $\left(90.9 \mathrm{mg} \mathrm{m}^{-2}\right.$ ), while integrated POC data increased steadily from the PAP to the IB (556 to $1105 \mathrm{mmol} \mathrm{m}^{-2}$ ), but decreased again over the IS $\left(802 \mathrm{mmol} \mathrm{m}^{-2}\right)$ (Fig. 11c).

\section{Discussion}

\subsection{Bloom development - general features}

The North Atlantic bloom started in April south east of our transect near the European coasts and developed towards the northwest during May, where the spatial coverage of the bloom was largest (Fig. 12). In June, the highest concentrations of both surface Chla and calcite were detected, as evidenced by the composite monthly SeaWiFs images (Fig. 12c and g). According to these satellite images, surface phytoplankton biomass was lower over the PAP region, around the southern part of our transect, from $45^{\circ} \mathrm{N}$ to $52^{\circ} \mathrm{N}$ (St. 1 to 10), whereas an intense surface accumulation of both Chla and calcite was observed from the Rockall Hatton Plateau to the Icelandic shelf. Our data (Fig. 8a) was in good agreement with these global features, with low concentrations of Chla in the upper $100 \mathrm{~m}$ in the PAP region then increasing above $1 \mu \mathrm{g} \mathrm{L}{ }^{-1}$ from approximately $52^{\circ} \mathrm{N}$ to $66.5^{\circ} \mathrm{N}$. The intense Chl $a$ accumulation south of Iceland visible on Fig. 12c coin- cided with the slight increase of Chla surface concentrations measured at $60^{\circ} \mathrm{N}$, but the intense subsurface $(25 \mathrm{~m}) \mathrm{Chl} a$ peak measured on the IS (Fig. 8a) was not visible on the satellite imagery, probably due to the depth of this peak. Indeed, satellites only peer through the near surface to a depth equivalent to 1/extinction coefficient. Overall, the monthly Chla composite satellite data was very well matched by our surface Chla data, both in general trends and concentrations.

The calcite surface distribution was very patchy as shown in the composite image (Fig. 12g) making comparisons with in situ data difficult, but the range of concentrations observed (between 1 and $10 \mu \mathrm{mol} \mathrm{L}^{-1}$ ) was identical to the range of our PIC measurements (Fig. 9a). The relative absence of calcite at the southern end of the transect shown by the satellite composite was in good agreement with PIC distribution, which was below $1 \mu \mathrm{mol} \mathrm{L}^{-1}$ on average in this region (south of $50^{\circ} \mathrm{N}$ ). The strong calcite increase visible over the northern half of the RHP as well as the very large peak observed over the IS were also well reproduced by our data. However, the highest PIC concentrations of the IS peak ranged between 2 and $10 \mu \mathrm{mol} \mathrm{L}^{-1}$, while satellite data showed calcite concentrations close to $30 \mu \mathrm{mol} \mathrm{L}-1$ over this area. The weekly composite image from the end of the cruise (26 June-3 July 2005) corresponding closest to the sampling period of the IS stations showed reduced calcite levels, closer to $3 \mu \mathrm{mol} \mathrm{L}{ }^{-1}$ which is in better agreement with our data. Weekly MODIS composite images (not shown) reveal that the largest coccolithophore bloom developing west of Iceland occurred between the end of May and mid-June, and was subsiding by the time we sampled the IS. It is also known that detached coccoliths can accumulate in the surface layer and that these particles have a very high reflective index, which may bias 

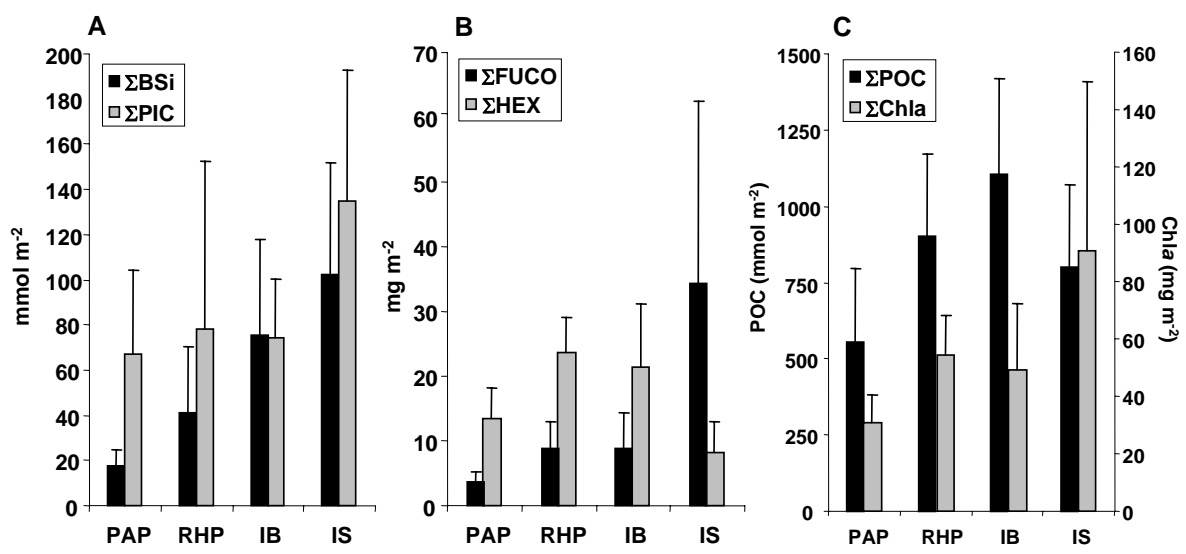

Fig. 11. 0-200 $\mathrm{m}$ integrated region averages and standard deviation (error bars) of (A) Biogenic silica ( $\Sigma$ BSi) and Particulate Inorganic

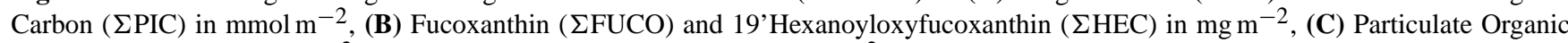
Carbon ( $\Sigma$ POC) in mmol $\mathrm{m}^{-2}$ and Total Chlorophyll $a(\Sigma \mathrm{TChl} a)$ in $\mathrm{mg} \mathrm{m}^{-2}$.

satellite estimations. We emphasize that comparing satellite images to in situ data is not trivial and that monthly composites cannot be expected to represent local sites sampled during the cruise. However, weekly images were too obscured by cloud cover to be useful. Our point is to show that despite potential large meso-scale features, the general trends of surface Chla and calcite measured during the cruise in terms of range of concentrations and main features could be reflected by composite satellite images. Furthermore, we show in the following section that in situ PIC and HEX data were poorly correlated, which suggest that satellite calcite data cannot be directly converted to coccolithophore abundance. Our cruise transect, sampled over a month, represents the South-North variability of different biological and hydrological provinces but also integrates the bloom temporal propagation northward. Thus, regional comparisons described below account for both spatial and temporal variability, and cannot be considered a true synoptic view of a bloom situation. Furthermore, care must be taken in extrapolating surface Chl $a$ data, which are often poorly correlated to water column integrated data, as was shown by Gibb et al. (2001) who demonstrated that conclusions derived from latitudinal differences in surface Chl $a$ were opposite to those derived from integrated Chla data.

\subsection{Community structure and characteristics of the NEA phytoplankton bloom}

We first present a short non-exhaustive synthesis of previous cruises carried out in the same area during spring in order to summarize the main characteristics of the spring/summer phytoplankton blooms, before comparing these studies with our results. The Biotrans site (at $47^{\circ} \mathrm{N}, 20^{\circ} \mathrm{W}$ ) characterized pigments between the end of June to mid July 1988 revealing that HEX (prymnesiophytes) was the dominant pigment for the nanoplankton size fraction while PERI (di- noflagellates) was the major pigment in the microplankton size class (Williams and Claustre, 1991). Relatively nondegraded prymnesiophyte pigments were observed at depth, suggesting aggregation and subsequent rapid sedimentation of prymnesiophytes. One year later, Llewellyn and Mantoura (1996) sampled stations on the $20^{\circ} \mathrm{W}$ meridian from $47^{\circ} \mathrm{N}$ to $60^{\circ} \mathrm{N}$ over the same period (first NABE cruise of JGOFS) and found that by mid-July diatoms dominated the spring bloom at $60^{\circ} \mathrm{N}$ while prymnesiophytes were more important at $47^{\circ} \mathrm{N}$, where the first spring bloom was already over.

The phytoplankton bloom was again sampled at $47^{\circ} \mathrm{N}$ earlier in the season in 1990, and results indicated that diatoms (23-70\%) and prymnesiophytes (20-40\%) dominated the Chla biomass in the first stage of the bloom during early May, while prymnesiophytes became dominant (45-55\%) in the second phase from the end of May to mid-June (Barlow et al., 1993). The latter study reported a pigment maxima at 5-15 $\mathrm{m}$ depth with a rapid decrease below that depth in the development phase, while at the peak of the bloom, diatoms dominated throughout the water column down to $300 \mathrm{~m}$. In the post-bloom phase, prymnesiophytes dominated the upper $20 \mathrm{~m}$ with diatoms more abundant in deeper waters. The following year, in 1991, a large coccolithophore bloom was encountered south of Iceland between 60 and $61^{\circ} \mathrm{N}$, between the end of June and early July (Fernandez et al., 1993).

During the PRIME program in July 1996, the surface phytoplankton community was dominated by prymnesiophytes between 37 and $61.7^{\circ} \mathrm{N}$, and a constant northward increase in relative diatom contribution was observed (Gibb et al., 2001). More recently, during the seasonal POMME study carried out in 2001, prymnesiophytes dominated the phytoplankton during March and April between 39 and $43^{\circ} \mathrm{N}$ except for a transition period in April when diatoms dominated at the northernmost site $\left(43^{\circ} \mathrm{N}\right)(\mathrm{H}$. Claustre, personal communication, 2001; Leblanc et al., 2005). 


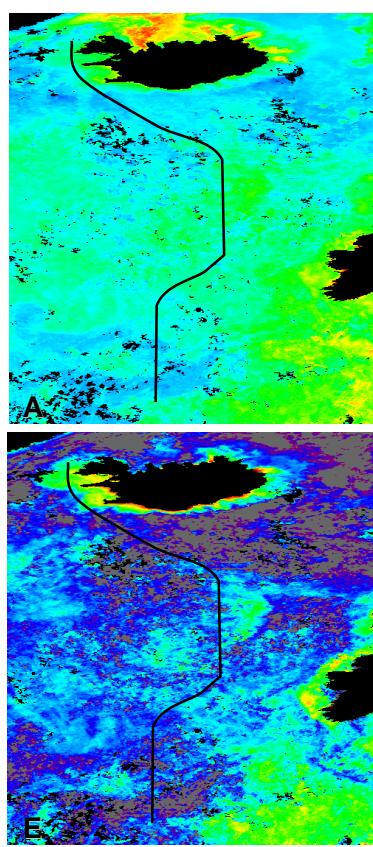

April

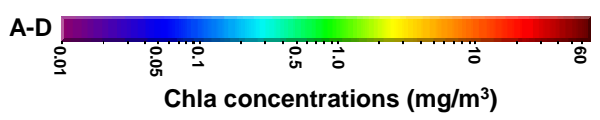

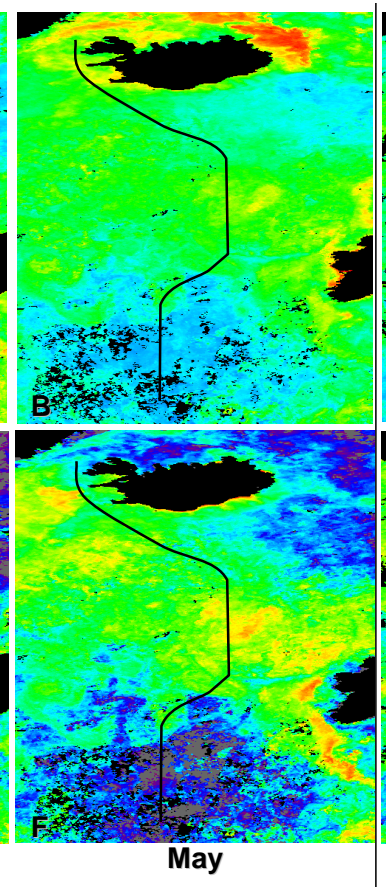
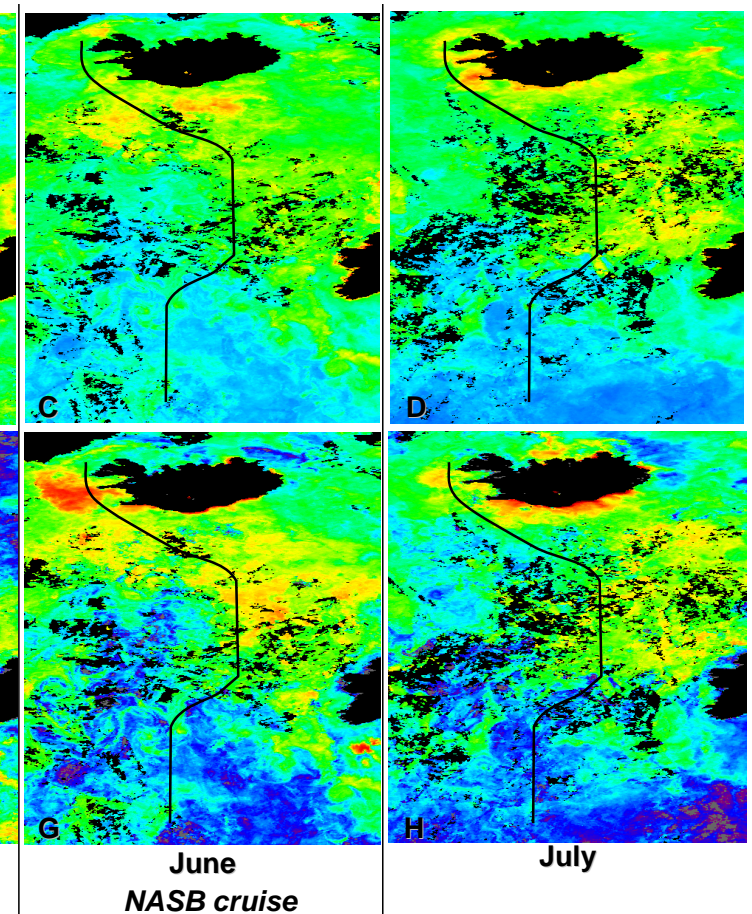

July

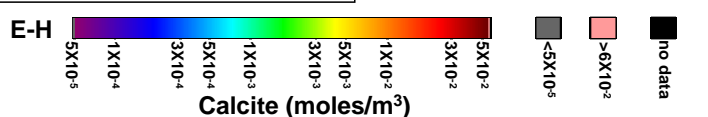

Fig. 12. Surface monthly satellite MODIS Chla (A-D) and calcite (E-H) images obtained from the Level 3 browser at http://oceancolor. gsfc.nasa.gov/ for 2005. The black line indicates the cruise track and the framed images (C and G) the cruise sampling period (June).

The recurrent scenario emerging from these previous studies is that diatoms dominate the early bloom stages, sometimes co-occurring with prymnesiophytes or dinoflagellates, and tend to be outcompeted by prymnesiophytes during later stages of the spring bloom due to changing light and nutrient availability and possibly grazer control. This temporal succession is also accompanied by a change in vertical phytoplankton community structure towards the end of the spring bloom with prymnesiophytes occupying the stratified surface layer $(0-30 \mathrm{~m})$ while diatoms tend to dominate lower depths (30-300 m) sometimes well below the MLD.

Our observations collected during the 2005 NASB study are in good agreement with this proposed scenario. In June, we found evidence of the propagation of the spring bloom northward, with Chla increasing from the PAP region to the IS (Figs. 8a and 13c). There was a general decrease in phytoplankton size structure from North to South, which was also observed during NABE (Sieracki et al., 1993). The pigment data showed a large prymnesiophyte bloom over both the RHP and IB, while diatoms were mostly found over the IB and IS (Figs. 10, 11 and 13b). The relative vertical distribution of diatoms and prymnesiophytes along our transect was also similar to that observed during the PRIME study (Gibb et al., 2001) in that HEX dominated the surface layer, while FUCO:HEX ratios $>1$ were found below $50 \mathrm{~m}$ (Fig. 10c).
Overall, the correlation between HEX and PIC was very poor for the entire cruise and may reflect a large contribution of Phaeocystis pouchetii, wherever HEX was not associated with PIC accumulation (St. 6, St. 27 to 30) and the temporal mismatch between coccolithophore biomass and coccolith concentration. Another explanation would be the presence of naked coccolithophores, but we have no data to substantiate this hypothesis.

The former reason is confirmed in Table 2, which summarizes the significance of correlations between the diatom and prymnesiophyte/coccolithophore indicators (BSi, FUCO, PIC, HEX) with the other main biogeochemical variables such as nutrients and biomass data. The PIC data stand out in this table as the one parameter that is most poorly correlated to any of the other variables. PIC and HEX were never significantly correlated and this is true regardless of testing the whole data set or testing each region separately. A poor correlation was also found in another study in the North Atlantic for a global data set $(n=130)$ on the same transect from $37^{\circ} \mathrm{N}$ to $59^{\circ} \mathrm{N}$, with significant PIC-HEX correlations found only for underway data and for data collected at $59^{\circ} \mathrm{N}$ (but for a very small data subset, $n=11$ ) (Gibb et al., 2001).

These results emphasize the difficulties in using bulk pigment and mineral indicators for a group such as coccolithophores. Both the cellular biomineral and pigment 
Table 2. Spearman-rank correlation coefficients $\left(r_{s}\right)$ calculated for the diatom and coccolithophore bulk indicators (BSi, FUCO, PIC, HEX) with the other main biogeochemical data for the complete data set (All) and each region (PAP, RHP, IB and IS). Correlations are considered significant when $p<0.01$ (two-tailed). Degrees of freedom were comprised between 132 and 243 for all regions, between 27 and 64 for the PAP region, between 45 and 124 for the RHP region, between 22 and 57 for the IB region and between 31 and 63 for the IS region. Non-significant correlations are indicated in italic, and strong correlations $\left(r_{s}>0.5\right.$ or $\left.<-0.5\right)$ are indicated in bold.

\begin{tabular}{|c|c|c|c|c|c|c|c|c|c|c|c|c|c|c|}
\hline & & $\mathrm{DSi}$ & DIN & DIP & $\mathrm{NH}_{4}$ & FUCO & HEX & TEP & POC & PON & POP & PIC & $\mathrm{BSi}$ & TChla \\
\hline \multirow[t]{4}{*}{ All } & $\mathrm{BSi}$ & $n s$ & $n s$ & $n s$ & 0.279 & 0.794 & 0.234 & 0.623 & 0.463 & 0.412 & 0.520 & 0.306 & - & 0.607 \\
\hline & Fuco & -0.289 & -0.358 & -0.316 & 0.185 & - & 0.615 & 0.801 & 0.698 & 0.677 & 0.799 & 0.428 & 0.794 & 0.921 \\
\hline & PIC & $n s$ & $n s$ & $n s$ & $n s$ & 0.428 & $n s$ & 0.396 & 0.285 & 0.280 & 0.390 & - & 0.306 & 0.420 \\
\hline & HEX & $-\mathbf{0 . 5 0 7}$ & -0.391 & -0.386 & $n s$ & 0.615 & - & 0.580 & 0.729 & 0.679 & 0.670 & $n s$ & 0.234 & 0.746 \\
\hline \multirow[t]{4}{*}{ PAP } & $\mathrm{BSi}$ & -0.343 & $n s$ & $n s$ & 0.404 & 0.599 & 0.129 & $n s$ & $n s$ & $n s$ & 0.308 & $n s$ & - & $n s$ \\
\hline & Fuco & -0.684 & -0.545 & 0.478 & $n s$ & - & 0.876 & 0.478 & 0.860 & 0.838 & 0.778 & $n s$ & 0.599 & 0.904 \\
\hline & PIC & $n s$ & $n s$ & $n s$ & $n s$ & $n s$ & $n s$ & $n s$ & $n s$ & $n s$ & $n s$ & - & $n s$ & $n s$ \\
\hline & HEX & -0.818 & -0.728 & -0.677 & $n s$ & 0.876 & - & 0.655 & 0.777 & 0.827 & 0.834 & $n s$ & $n s$ & 0.949 \\
\hline \multirow[t]{4}{*}{ RHP } & $\mathrm{BSi}$ & -0.562 & $n s$ & -0.406 & $n s$ & 0.802 & 0.579 & 0.490 & 0.640 & 0.532 & 0.646 & $n s$ & - & 0.630 \\
\hline & Fuco & -0.793 & -0.675 & -0.567 & $n s$ & - & 0.871 & 0.722 & 0.733 & 0.620 & 0.827 & 0.381 & 0.802 & 0.906 \\
\hline & PIC & $n s$ & $n s$ & $n s$ & $n s$ & 0.381 & $n s$ & $n s$ & $n s$ & $n s$ & $n s$ & - & $n s$ & 0.396 \\
\hline & HEX & -0.740 & -0.713 & -0.638 & $n s$ & 0.871 & - & 0.830 & 0.862 & 0.772 & 0.874 & $n s$ & 0.579 & 0.944 \\
\hline \multirow[t]{4}{*}{ IB } & $\mathrm{BSi}$ & -0.505 & $n s$ & -0.371 & $n s$ & 0.746 & 0.431 & 0.647 & 0.391 & $n s$ & 0.366 & $n s$ & - & 0.464 \\
\hline & Fuco & -0.511 & $n s$ & -0.439 & $n s$ & - & 0.846 & 0.893 & 0.785 & 0.734 & 0.709 & $n s$ & 0.746 & 0.890 \\
\hline & PIC & $n s$ & $n s$ & $n s$ & $n s$ & $n s$ & $n s$ & $n s$ & $n s$ & $n s$ & 0.652 & - & $n s$ & 0.540 \\
\hline & HEX & -0.560 & -0.494 & -0.605 & $n s$ & 0.846 & - & 0.855 & 0.907 & 0.899 & 0.845 & $n s$ & 0.431 & 0.974 \\
\hline \multirow[t]{4}{*}{ IS } & $\mathrm{BSi}$ & $n s$ & $n s$ & $n s$ & $n s$ & 0.563 & $n s$ & 0.536 & $n s$ & $n s$ & 0.423 & $n s$ & - & 0.545 \\
\hline & Fuco & -0.438 & -0.561 & -0.598 & $n s$ & - & $n s$ & 0.670 & 0.692 & 0.649 & 0.815 & $n s$ & 0.563 & 0.950 \\
\hline & PIC & $n s$ & $n s$ & $n s$ & $n s$ & $n s$ & $n s$ & $n s$ & $n s$ & $n s$ & $n s$ & - & $n s$ & $n s$ \\
\hline & HEX & -0.417 & -0.494 & $n s$ & -0.547 & $n s$ & - & 0.404 & 0.434 & 0.424 & $n s$ & $n s$ & $n s$ & $n s$ \\
\hline
\end{tabular}

contents are highly variable and depend on the cell's physiological status and species. During their growth, particularly in senescence, some coccolithophores shed their coccoliths. These coccoliths are too small to sink and tend to accumulate in the surface layer. This further decouples PIC from the biomass of living coccolithophores. For instance, the remnants of a coccolithophore bloom is indicated by the presence of PIC in the surface layer from St. 31 to 35 over the IS, but with no HEX accumulation, likely reflecting the presence of detached coccoliths while pigments and organic carbon have been lost, e.g. sedimented, degraded or grazed. Surface increases in HEX without similar PIC accumulation were also observed (for instance at St. 17) and could indicate the presence of either uncalcifying strains of coccolithophores or more likely an increased contribution of Phaeocystis pouchetii. The correlation between PIC with HEX, even though not significant, increased slightly over the RHP and IB regions $\left(r_{s}=0.36\right.$ and 0.44 , respectively) where it can be hypothesized that the contribution of coccolithophores vs. Phaeocystis pouchetii increased.

BSi and FUCO concentrations were on the other hand always significantly correlated (Table 2 ), with correlation coefficients $\left(r_{s}\right)$ of 0.56 to 0.80 . The entire data set showed a very strong correlation with an $r_{s}$ value of 0.79 , which was also very high over the RHP $(0.80)$ and the IB (0.75). Slightly lower coefficients were found over the PAP $\left(r_{s}=0.59\right)$ and IS $\left(r_{s}=0.56\right)$. These weaker correlations can be explained by the presence of more senescent cells with low pigment contents or empty diatom frustules. This was most likely the case over the IS where high BSi concentrations extended as deep as $200 \mathrm{~m}$ (Fig. 9b), well below the $Z_{e}$ depth of $\sim 20 \mathrm{~m}$ (Fig. 3), while most of the Chla was confined to the first $50 \mathrm{~m}$ (Fig. 8a). Hence it is unlikely that diatoms were still growing as deep as $200 \mathrm{~m}$ and this signal more probably represents sinking diatoms. This is further confirmed by phaeophyllides concentrations (data not shown), which were much higher in the IB and IS regions than in the PAP and RHP regions. Some interference with lithogenic silica (LSi) near bottom $(75 \mathrm{~m}$ only at St. 35 and 36) could also have occurred since BSi data were not corrected for LSi during analysis. Phaeocystis spp. is also known to produce FUCO (Schoemann et al., 2005) and could explain differences between BSi and FUCO comparisons. However, in our study, the presence of FUCO was always matched by the presence of $\mathrm{BSi}$, and we often observed the presence of BSi without FUCO. Hence, it is likely that in our study FUCO was mostly indicative of diatoms.

More surprisingly, FUCO and HEX were highly correlated during our survey in the PAP, RHP and IB regions $\left(r_{s}=0.88\right.$, 0.87 and 0.85 , respectively) but not over the IS, where FUCO was overall dominant. Even though FUCO concentrations 
were very low in the first three regions, the patterns of distribution seemed to match closely those of HEX, with a notable accumulation at $59.5^{\circ} \mathrm{N}$ (St. 23) and $57^{\circ} \mathrm{N}$ (St. 17). Hence, even though not very abundant, diatoms were cooccurring with prymnesiophytes from $45^{\circ} \mathrm{N}$ to $63^{\circ} \mathrm{N}$, which were dominating the phytoplankton community, except over the IS.

The strongest correlation was found between FUCO and TChl $a$, with highly significant and elevated $r_{s}$ values, from 0.89 to 0.95 in the different region, and an $r_{s}$ value of 0.92 for the entire data set $(d f=243)$. Significant correlations were found between BSi and Chla for the entire transect, PAP, RHP and IS regions ( $r_{s}=0.46$ to 0.63$)$ but were not significantly correlated over the IB. Similarly to FUCO, HEX was highly significantly correlated to TChl $a$, with $r_{s}$ values between 0.75 (all data) and 0.97 (IB), except in the IS where the correlation was not significant. Highly significant correlations were also found for both HEX and FUCO with other biomass parameters such as POC, PON and POP. These results indicate that diatoms and prymnesiophytes were major components of the late June-July phase of the North Atlantic Spring Bloom, and that they co-occurred in most regions, despite large differences in terms of abundance.

Pigment data were also much better correlated to Chla and particulate $\mathrm{C}, \mathrm{N}, \mathrm{P}$ data than biominerals, which is expected as pigments are characteristic of fresh material whereas biominerals may persist in the water associated with senescent cells, or remain suspended. The discrepancy in pigment to mineral correlations indicates that the latter situations were encountered during our cruise, with large amounts of sinking detrital opal and suspended calcium carbonate in the water column. Hence, bulk biominerals measurements are not a good indicator for living organisms.

Correlations between nutrients and BSi, FUCO, PIC, HEX data generally yielded a negative $r_{s}$ value, reflecting the fact that biomass accumulation is inversely related to nutrient consumption. Both FUCO and HEX were significantly correlated to depletion of all nutrients but the strongest correlations occurred over the PAP and IB regions, where biomass accumulation was highest. In general, ammonium was not correlated to any of these parameters except in the IS where $\mathrm{HEX}$ and $\mathrm{NH}_{4}$ were significantly correlated $\left(r_{s}=0.54\right)$. HEX was significantly correlated to DSi depletion in all regions. In particular, HEX and DSi showed strong correlations $\left(r_{s}=0.82\right)$ in the PAP and RHP $\left(r_{s}=0.74\right)$ regions. Accumulation of prymnesiophytes, indicated by HEX, indeed occurred in the surface layer where DSi appeared depleted. This correlation corroborates the hypothesis of an earlier diatom bloom which led to depleted surface silicic acid levels and a subsequent decline of diatoms, allowing the prymnesiophytes to develop and become dominant.

Finally, the occurrence of TEP was significantly correlated to the FUCO, HEX and BSi distribution and to a lesser degree with PIC. Diatoms are known to produce large amounts of TEP and good correlations between TEP and Chla in diatom dominated systems are commonly found (Passow, 2002; Passow et al., 2001). The distribution patterns of BSi and TEP (Figs. 9 and 12) also show a good overlap, particularly for the sites of high BSi concentration at the RHP/IB and IB/IS transitions $\left(60^{\circ}\right.$ and $\left.63.2^{\circ} \mathrm{N}\right)$. Below $40 \mathrm{~m}$ depths pigment concentrations were low, even when TEP and $\mathrm{BSi}$ were high, suggesting that these elevated BSi signals document the sedimentation of diatom aggregates. Unaggregated TEP do not sink (Azetsu-Scott and Passow, 2004), but form the matrix of aggregates (Passow and Alldredge, 1995), which are then prone to sink rapidly due to their large size. TEP distribution, in particular, the extensions at depth at St. 24, 31 and 35 closely matched the distribution of $\mathrm{BSi}$; thus their occurrence at depth is an indication of sinking TEP-rich diatom aggregates. TEP also correlated well with HEX distribution, indicating that the prymnesiophyte bloom generated abundant amounts of TEP as well. Production of TEP by E. huxleii has been observed in a mesocosm experiment (Engel et al., 2004), but it has not before been shown that TEP is produced abundantly during natural coccolithophore blooms. Phaeocystis is also known to produce TEP (Riebesell et al., 1995; Hong et al., 1997) which could explain the good agreement between HEX and TEP distributions in the areas where HEX and PIC are not well correlated (St. 6 and St. 11 to 17).

\subsection{Phytoplankton control factors}

The situation encountered over the transect during the month of June was net autotrophic (Cottrell et al., 2008). The PAP region was characterized by the lowest phytoplankton biomass, as well as by the highest contribution of the smaller size-class such as nano- and picophytoplankton. In addition, the primary production rates in this area $\left(50\right.$ to $\left.55^{\circ} \mathrm{N}\right)$ were lower relative to the other regions along our transect (Cottrell et al., 2008). This correlates with the deeper nutricline depths encountered in this province ( $<50 \mathrm{~m}$ at most sites) and the lowest nutrient availability in the euphotic layer. Light was probably not a limiting factor, as the euphotic depth was the deepest in this region and exceeded $\mathrm{Zm}$ at all sites. Temperature did not seem to be controlling Chla accumulation in June 2005 either, in contrast to phytoplankton distribution in the Sargasso Sea as evidenced by Rowe et al. (2008). From satellite imagery (Fig. 12), it seems that Chla accumulation in that area was never very high during the initiation of the spring bloom. This may reflect the shallower winter mixed layer in the PAP compared to the northern part of the transect which would lead to diminished nutrient inputs in the surface layer and nutrient limitation early on in the productive season. For the year 2005, the MLD was much deeper south of Iceland than over the central part of the NEA corresponding to the PAP until April (Mercator data available at http:// bulletin.mercator-ocean.fr/html/welcome_fr.jsp). From May to July, this trend was much less obvious. Hence the latitudinal trend of the MLD during winter and early spring, but also 
the highest store of nutrients towards the North (Sarmiento and Grüber, 2006) may reflect the South-North increase in nutrient stocks in the stratified surface layer during the productive season. DSi concentrations as low as $0.2 \mu \mathrm{M}$ and Si:N ratios below 0.2 (Figs. 4 and 5) also indicate Si consumption by diatoms prior to our sampling period. BSi and FUCO were however negligible, indicating that the diatom bloom had subsided by June, and either sank out or was grazed. The elevated N:P ratio (close to 40 ) at St. 2 at the southern end of the transect $\left(46^{\circ} \mathrm{N}\right)$ may reflect the potential presence of nitrogen fixers.

The RHP and IB regions were characterized by relatively high DIN $(>4 \mu \mathrm{M})$ and DIP $(0.2-0.4 \mu \mathrm{M})$ concentrations in the upper $25 \mathrm{~m}$ while DSi was at the detection limit at $60^{\circ} \mathrm{N}$, where a large BSi accumulation was found. This coincided with a moderate increase in FUCO, which remained low compared to the abundance of HEX. These data suggest the occurrence of a previous diatom bloom, and the persistence of detrital BSi in the process of sinking out or being grazed, as shown by the deep extension of BSi down to almost 150 $\mathrm{m}$ well below the euphotic layer. Increased phaeopigments concentrations (data not shown) in the upper $50 \mathrm{~m}$ indicate active grazing of biomass. Viral production was fairly constant throughout the $20^{\circ} \mathrm{W}$ transect, but increased drastically at St. $22\left(59^{\circ} \mathrm{N}\right)$, on the southern edge of this feature (Rowe et al., 2008) indicating potential local control of biomass by viral lysis. This bloom seemed to have been followed by a prymnesiophyte bloom, with large HEX concentrations clearly confined to the surface layer, together with some accumulation of PIC. The highest BSi and HEX accumulations coincided with the presence of a frontal structure at $60^{\circ} \mathrm{N}$ (St. 24 and 25) and a doming of isopycnals at this site. However this accumulation feature extended across it in both direction, but with more moderate biomass values. $Z_{e}$ depths were shallow in both areas $(20-30 \mathrm{~m})$ but light did not seem to be a limiting factor for growth.

Continuing northward, a second front was passed near the Icelandic Shelf Break (between $61.6^{\circ} \mathrm{N}$ and $63.2^{\circ} \mathrm{N}$ ) and was characterized by a small increase in microphytoplankton Chla associated with an increase in FUCO in the upper $30 \mathrm{~m}$, and with a large accumulation of $\mathrm{BSi}(\sim 1 \mu \mathrm{mol} \mathrm{L}-1)$ extending as deep as $200 \mathrm{~m}$. This diatom bloom seems to have been stimulated by the surfacing of the DSi isopleths at St. 31 with concentrations up to $1.4-1.6 \mu \mathrm{M}$ in the surface layer. BSi concentrations as high as $1 \mu \mathrm{mol} \mathrm{L}^{-1}$ which extended to the sea floor of the IS together with the absence of detectable pigments below $40 \mathrm{~m}$ very probably reflected the sinking of empty diatom frustules along the very steep 27.4 isopycnal (Fig. 2), potentially mediated by TEP aggregation. A large accumulation of phaeopigments (data not shown), with a maximum concentration found at $50 \mathrm{~m}$ at $61.6^{\circ} \mathrm{N}$ could also indicate a rapid export of BSi through zooplankton faecal pellets. Another possible explanation would be contamination by bottom sediment resuspension of previously sedimented diatom cells, or by lithogenic silica (which was not measured in our samples), but the similar deep extension of TEP and BSi from the surface argue against this hypothesis.

Finally the IS was characterized by the highest biomass accumulation of the transect, which was reflected by an increased surface consumption of nutrients, particularly in DIN which showed the lowest concentrations encountered during the cruise $(<1 \mu \mathrm{M})$. Phytoplankton communities on the IS were mixed both spatially and vertically, with a high surface accumulation of picophytoplankton (chlorophytes and prasinophytes, data not shown) and probably also detached coccoliths as PIC was elevated but HEX concentrations were moderate. This community was found between 63 and $65^{\circ} \mathrm{N}$ (St. 31 to 35 ) and was present in a highly stratified water column above the 27.3 ispopycnal (Fig. 2). The highest BSi and FUCO concentrations of the transect were constrained to the subsurface below $25-30 \mathrm{~m}$ north of $66^{\circ} \mathrm{N}$, where diatoms were clearly the major contributing group. This intense diatom growth seems to have occurred where cold polar melt waters (PW) encountered modified North Atlantic Waters (MNAW) over the IS.

Surface PW were not characterized by any increased nutrient load at the time of sampling. We hypothesize that this diatom bloom was seeded over the shelf following the retreat of the ice edge earlier in the season, which resulted in the depletion of all nutrients by the end of June. The FUCO patch was centred around $25-30 \mathrm{~m}$ north of $66^{\circ} \mathrm{N}$ and did not extend below $50 \mathrm{~m}$, while BSi was found in elevated concentrations all the way down to the seafloor $(\sim 125 \mathrm{~m})$. This again would indicate that the BSi found at depth was mostly detrital and in the process of sinking out of the surface layer in aggregates similarly to what was observed at $63.2^{\circ} \mathrm{N}$. Large amounts of phaeopigments over the IS also suggest active grazing control of this subsurface diatom bloom.

Regarding the role of trace metals on phytoplankton growth in the NEA, our surface trace metal data show that neither Fe nor Zn were highly depleted, with dissolved concentrations of 0.7 and $0.8 \mathrm{nM}$ on average. Yet, three trace metal addition experiments in which $2 \mathrm{nM} \mathrm{Fe}$ and $2 \mathrm{nM} \mathrm{Zn}$ were added were carried out during the transect (at $51.5^{\circ}, 56^{\circ}$ and $63.5^{\circ} \mathrm{N}$ ), and all resulted in an increase of Chla after 6 days by a factor of 1.2 to 1.9 in the $+\mathrm{Fe}$ treatments compared to a control, and in a stimulation of the $>20 \mu \mathrm{m}$ size fraction (data not shown). Zn additions did not induce any increase in Chla. Despite relatively high Fe concentrations, moderate Fe limitation and co-limitation with DSi have already been observed in the same region between 39 and $45^{\circ} \mathrm{N}$ in the early stages of the spring bloom (Blain et al., 2004). More recently, Fe limitation was similarly established in the central North Atlantic (Moore et al., 2006).

Interestingly, particulate $\mathrm{Fe}$ increased drastically from South to North, similarly to the $\Sigma$ BSi and $\Sigma$ FUCO patterns, which could reflect the larger $\mathrm{Fe}$ requirements by diatoms, while oceanic coccolithophores are known to have a very low Fe requirement (Brand, 1991; Sunda and Huntsman, 1995a). 
On the other hand particulate $\mathrm{Zn}$ increased from the PAP to the IB, but decreased over the IS similarly to the $\Sigma$ HEX and $\Sigma$ POC patterns, which could reflect a higher utilization of Zn by prymnesiophytes, notably over the IB region. Previous work by (Kremling and Streu, 2001) reported trace metal concentrations along the same transect as in our study and during the same season. More than half of their $\mathrm{Zn}$ measurements were below the detection limit, but the authors argued against the "Zn hypothesis" between 40 and $60^{\circ} \mathrm{N}$ because of high Co concentrations, as Co and $\mathrm{Zn}$ are known to substitute for one another (Sunda and Huntsman, 1995b). Our data do not allow further interpretation, given that they are large regional surface averages, and that complex substitutions of metals, notably $\mathrm{Zn}, \mathrm{Co}$ and $\mathrm{Cd}$ are also at play (Morel et al., 2003), but moderate Fe limitation was likely preventing a complete drawdown of surface nutrients during June between 45 and $66^{\circ} \mathrm{N}$.

\subsection{Si depletion - a general feature of the NEA}

At the end of the first NABE program in the NEA, it remained unclear whether the sequential depletion of $\mathrm{Si}$ and $\mathrm{N}$ was common or if the year 1989 was an unusual year (Sieracki et al., 1993). Since then, several other programs such as BIOTRANS, BOFS, PRIME and POMME conducted in the NEA during the productive season have reported Si depletion prior to $\mathrm{N}$ exhaustion later in the season, as well as consistently low Si:N ratios in the surface layer (Lochte et al., 1993; Sieracki et al., 1993; Passow and Peinert, 1993; Taylor et al., 1993; Savidge et al., 1995; Bury et al., 2001) that were well below the usual 1:1 requirement for diatoms (Brzezinski, 1985). From earlier work during the POMME program, it was shown that winter surface silicic acid availability between 40 and $45^{\circ} \mathrm{N}$ was already $2-3 \mu \mathrm{M}$ lower than nitrate and that this deficit increased with depth, with a 5-7 $\mu \mathrm{M}$ difference between DSi and DIN concentrations at $1000 \mathrm{~m}$ (Leblanc et al., 2005). Uptake kinetics measured in this region also suggested potential diatom growth limitation by ambient Si concentrations (Leblanc et al., 2005). These low surface Si:N ratios may reflect the deficiency in Si compared to $\mathrm{N}$ of North Atlantic intermediate and deep waters, as can be observed on the WOCE sections between 30 and $60^{\circ} \mathrm{N}$ (Sarmiento and Gruber, 2006). Biogenic silica produced by diatoms during the spring bloom sinks with a higher efficiency to depth, while other nutrients are more readily remineralized in the water column. This process, termed the silica pump (Dugdale et al., 1995), causes a preferential loss of Si to the sediments compared to N, P and C. Deep waters circulating in the NA basin have only recently been formed through winter convection and do not carry the same Si load that older Pacific deep waters do for instance, which are at the end of the conveyor belt circuit and received surface biogenic material along its path. Hence, the chronic Si deficiency of the NA is likely to be a permanent feature and can be explained by global oceanic circulation. The moderate
Fe limitation which has been invoked in the NEA and observed through several enrichment experiments (Blain et al., 2004; Moore et al., 2006; Leblanc, unpublished data) could furthermore enhance the efficiency of the Si pump in this region. It is now accepted that Fe deficiency leads to increased cellular Si quotas in diatoms (Hutchins and Bruland, 1998; Hutchins et al., 1998; Takeda et al., 1998; Firme et al., 2003; Leblanc et al., 2005b) which could then increase the vertical decoupling of $\mathrm{Si}$ vs. $\mathrm{N}$ and $\mathrm{P}$, with more heavily silicifed cells sinking faster and less prone to dissolution in the surface waters.

Despite this the spring bloom is initiated by diatoms in this region, which rapidly consume the available Si before being outcompeted by coccolithophores, a group physiologically more adapted to the stratified and oligotrophic conditions that occur later in the season (Iglesias-Rodriguez et al., 2002). Even though Si availability does not directly control the initiation of the coccolithophore bloom, it plays a major role in structuring phytoplankton communities throughout the productive season. Understanding the succession of these major biomineralizing groups in this highly productive region of the NA is the key to understanding and quantifying the $\mathrm{C}$ export processes on a basin scale.

Diatoms and coccolithophores are likely to have very different impacts on the $\mathrm{C}$ export term. The respective roles of the minerals $\mathrm{SiO}_{2}$ and $\mathrm{CaCO}_{3}$ as ballast particles and vectors for POC export to depth is highly debated. The analyses of a large number of sediment trap data suggested that $\mathrm{CaCO}_{3}$ was a more efficient ballast mineral for POC (François et al., 2002; Klaas and Archer, 2002) but this assertion has recently been contested by new experimental work (Passow and De La Rocha, 2006; De La Rocha and Passow, 2007). Unfortunately, we do not have sediment trap data in this study to argue one way or the other. Leaving the ballast issue aside, diatoms and coccolithophores are known to have very different impacts on the biological pump. Diatoms tend to sediment quickly, either after mass flocculation events (which may be triggered by elevated TEP production) or through grazers faecal pellets, while some evidence show that grazing rates are reduced during a coccolithophore bloom (Huskin et al., 2001; Nejstgaard et al., 1997). Calcification furthermore results in a net outgassing of $\mathrm{CO}_{2}$ towards the atmosphere (albeit $p \mathrm{CO}_{2}$ solubility in surface waters increases as we move poleward), which also depends on photosynthetic activity and initial $p \mathrm{CO}_{2}$ levels in surface waters. Mechanisms of sedimentation of coccolithophores other than in faecal pellets are not clear. In contrast to diatoms, where the organic matter is trapped within the frustule after cell death, coccoliths are released into the water upon cell death (or earlier in some species), and are thus physically separated from the organic carbon of the coccolithophore. Both organic carbon and coccoliths could then aggregate if conditions are right, but other processes may become more important. Aggregation of whole coccolithophores has also been postulated (Cadee, 1985), but it has never been ascertained 
if the observed structures were true aggregates or appendicularian pseudo faeces. Formation of fast sinking aggregates leads to faster export of material to depth, thus enhancing the efficiency for $\mathrm{C}$ export. Hence, in our study, the presence of TEP closely associated to diatom and coccolithophore distribution may be an important vector for POC export for both types of phytoplankton.

\section{Conclusions}

The seasonal succession of the spring phytoplankton bloom in the North East Atlantic now seems better understood. The NASB data presented here corroborates previous observations gathered during the JGOFS era and the follow-up programs carried out in this oceanic region, as well as model scenarios for the spring bloom. The bloom is initiated by diatoms upon the onset of stratification and alleviation of light limitation. Diatoms are rapidly outcompeted due to severe $\mathrm{Si}$ limitation in the surface layer and potential $\mathrm{Fe}$ limitation may occur despite relatively high concentrations. The intensification of stratification (i.e. increased light and impoverished nutrient conditions) then leads to the development of a large coccolithophore bloom often located on the RHP and close to Iceland.

During our study the spring diatom bloom was waning, and abundant diatom biomass was constrained to the northern part of the transect over the IS, while coccolithophores were mainly dominant over the RHP and IB. These two phytoplankton groups were clearly dominating the autotrophic community, but the presence of Phaeocystis spp. was also suspected to be present in some regions. We show that measurements of bulk minerals or pigments are not sufficient to clearly establish the dominance of one group, as coccolithophores and Phaeocystis spp. both possess HEX while diatoms and Phaeocystis both possess FUCO. Hence, the need for systematic cell counts remain impossible to circumvent, but should become easier with the advent of semiautomatized counting and imaging devices.

We conclude that the unique combination of early Si depletion, along with sufficient $\mathrm{N}$ and $\mathrm{P}$ levels and water stratification processes may be the reason why we observe one of the planet's most extensive coccolithophore blooms in the NEA. Although the temporal succession between diatoms and prymnesiophytes seems established, the role of the major species succession within each group (namely the relative contribution of coccolithophores and Phaeocystis) still needs further assessment.

We suggest that focus now needs to be placed on export modes of this intense phytoplankton bloom. Further studies need to elucidate the net contribution of diatoms and coccolithophores to $\mathrm{C}$ export through a better quantification of the relative impact of processes such as grazing, TEP production, flocculation events and passive sinking. Finally, a challenge will be to understand how the dynamics of the North Atlantic
Bloom will respond to future changes in climate forcing, a question that was addressed during our study by parallel experiments examining the response of the same NAB communities sampled here to increasing $p \mathrm{CO}_{2}$ and temperature (Feng et al., 2009; Lee et al., 2009; Rose et al., 2009).

Acknowledgements. We thank the captain and crew of the R. V. Seward Johnson for their valuable help at sea. Grant support was provided by NSF grants OCE 0423418 (0741412), OCE 0722337 to DAH, OCE 0452409 to SWW, OCE 0422890 to GRD, OGB NA17EC1483 to CWB, DFG grant BE2634/2 to GMB and $\mathrm{CS}$, and by the Alfred Wegener Institute. We thank the NASA Goddard Space Flight Center's Ocean Biology Processing Group for making near-real time SeaWiFS data available during the cruise.

Edited by: E. Marañón

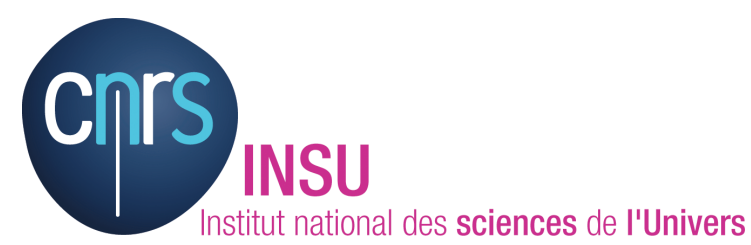

The publication of this article is financed by CNRS-INSU.

\section{References}

Aiken, J., and Bale, A. J.: An introduction to the Atlantic Meridional Transect (AMT) program, Prog. Oceanogr., 45, 251-256, 2000.

Azetsu-Scott, K. and Passow, U.: Ascending marine particles: Significance of transparent exopolymer particles (TEP) in the upper ocean, Limnol. Oceanogr., 49, 741-748, 2004.

Balch, W. M., Kilpatrick, K. A., and Trees, C. C.: The 1991 coccolithophore bloom in the central North Atlantic. 1. Optical properties and factors affecting their distribution, Limnol. Oceanogr., 41, 1669-1683, 1996.

Barlow, R. G., Mantoura, R. F. C., Gough, M. A., and Fileman, T. W.: Pigment signatures of the phytoplankton composition in the northeastern Atlantic during the 1990 spring bloom, Deep Sea Res. II, 40, 459-477, 1993.

Blain, S., Guieu, U., Claustre, H., Leblanc, K., Moutin, T., Queguiner, B., Ras, J., and Sarthou, G.: Availability of iron and major nutrients for phytoplankton in the northeast Atlantic Ocean, Limnol. Oceanogr., 49, 2095-2104, 2004.

Boyd, P. W. and Trull, T. W.: Understanding the export of biogenic particles in oceanic waters: Is there consensus?, Prog. Oceanogr., 72, 276-312, 2007.

Brand, L. E.: Minimum iron requirements of marine phyoplankton and the implications for the biogeochemical control of new production, Limnol. Oceanogr., 36, 1756-1771, 1991.

Brown, C. W. and Yoder, J. A.: Coccolithophorid blooms in the global ocean, J. Geophys. Res., 99, 7467-7482, 1994.

Bruland, K. W., Franks, R. P., Knauer, G. A., and Martin, J. H.: Sampling and analytical methods for the determination of copper, cadmium, zinc, and nickel at the nanogram per liter level in sea water, Anal. Chim. Acta, 105, 233-245, 1979. 
Brzezinski, M. A.: The SI:C:N ratios of marine diatoms : Interspecific variability and the effect of some environmental variables, J. Phycol., 21, 345-357, 1985.

Bury, S. J., Boyd, P. W., Preston, T., Savidge, G., and Owens, N. J. P.: Size-fractionated primary production and nitrogen uptake during a North Atlantic phytoplankton bloom: Implications for carbon export estimates, Deep-Sea Res. I, 48, 689-720, 2001.

Cadee, G. C.: Macroaggregates of Emiliana huxleyi in sediment traps, Mar. Ecol. Prog. Ser., 24, 193-196, 1985.

Claustre, H., Kerhervé, P., Marty, J. C., Prieur, L., Videau, C., and Hecq, J. H.: Phytoplankton dynamics associated with a geostrophic front : Ecological and biogeochemical implications, J. Mar. Res., 52, 711-742, 1994.

Cottrell, M. T., Michelou, V. K., Nemcek, N., DiTullio, G., and Kirchman, D. L.: Carbon cycling by microbes influenced by light in the northeast Atlantic Ocean, Aquat. Microb. Ecol., 50, 239250, doi:10.3354/AME01173, 2008.

De La Rocha, C. L. and Passow, U.: Factors influencing the sinking of POC and the efficiency of the biological carbon pump, DeepSea Res. II, 54, 639-658, 2007.

DiTullio, G. R. and Geesey, M. E.: Photosynthetic pigments in marine algae and bacteria, in: The encyclopedia of environmental microbiology, edited by: Bitton, G., John Wiley \& Sons, 24532470, 2002.

Ducklow, H. W. and Harris, R. P.: Introduction to the JGOFS North Atlantic bloom experiment, Deep Sea Res. II, 40, 1-8, 1993.

Dugdale, R. C., Wilkerson, F. P., and Minas, H. J.: The role of a silicate pump in driving new production, Deep-Sea Res. I, 42, 697-719, 1995.

Engel, A., Delille, B., Jacquet, S., Riebesell, U., Rochelle-Newall, E., Terbruggen, A., and Zondervan, I.: Transparent exopolymer particles and dissolved organic carbon production by Emiliania huxleyi exposed to different $\mathrm{CO}_{2}$ concentrations: A mesocosm experiment, Aquat. Microb. Ecol., 34, 93-104, 2004.

Eppley, R. W., Rogers, J. N., and McCarthy, J. J.: Half saturation constant for uptake of nitrate and ammonium by marine phytoplankton, Limnol. Oceanogr., 14, 912-920, 1969.

Feng, Y., Hare, C. E., Leblanc, K., Rose, J., Zhang, Y., DiTullio, G. R., Lee, P. A., Wilhelm, S. W., Rowe, J. M., Sun, J., Nemcek, N., Gueguen, C., Passow, U., Benner, I., and Hutchins, D. A.: The effects of increased $\mathrm{pCO}_{2}$ and temperature on the North Atlantic Spring Bloom: I. The phytoplankton community and biogeochemical response, Mar. Ecol. Prog Ser., 388, 13-25, 2009.

Fernandez, E., Boyd, P., Holligan, P. M., and Harbour, D. S.: Production of organic and inorganic carbon within a large-scale coccolithophore bloom in the northeast Atlantic Ocean, Mar. Ecol. Prog. Ser, 97, 271-285, 1993.

Firme, G. F., Rue, E. L., Weeks, D. A., Bruland, K. W., and Hutchins, D. A.: Spatial and temporal variability in phytoplankton iron limitation along the california coast and consequences for Si, N, and C biogeochemistry., Global Biogeochem. Cy., 17, 16.11-16.13, 2003.

François, R., Honjo, S., Krishfield, R., and Manganini, S.: Factors controlling the flux of organic carbon to the bathypelagic zone of the ocean, Global Biogeochem. Cy., 16, 1087, doi:10.1029/2001GB001722, 2002.

Gibb, S. W., Cummings, D. G., Irigoien, X., Barlow, R. G., Fauzi, R., and Mantoura, C.: Phytoplankton pigment chemotaxonomy of the northeastern Atlantic, Deep-Sea Res. II, 48, 795-823,
2001.

Gruber, N.: Anthropogenic $\mathrm{CO}_{2}$ in the Atlantic Ocean, Global Biogeochem. Cy., 12, 165-191, 1996.

Hansen, B. and Østerhus, S.: North Atlantic-nordic seas exchanges, Prog. Oceanogr., 45, 109-208, 2000.

Holligan, P. M., Fernandez, E., Aiken, J., Balch, W. M., Boyd, P., Burkill, P. H., Finch, M., Groom, S. B., Malin, G., and Muller, K.: A biogeochemical study of the coccolithophore, Emiliana huxleyi, in the North Atlantic, Global Biogeochem. Cy., 7, 879900, 1993.

Hong, Y., Smith Jr., W. O., and White, A.-M.: Studies on transparent exopolymer particles (TEP) produced in the Ross Sea (Antarctica) and by Phaeocystis antarctica (Prymnesiophyceae), J. Phycol., 33, 368-376, 1997.

Huskin, I., Anadon, R., Woodd-Walker, R. S., and Harris, R. P.: Basin-scale latitudinal patterns of copepod grazing in the Atlantic Ocean, J. Plankton Res., 23, 1361-1371, doi:0.1093/plankt/23.12.1361, 2001.

Hutchins, D. A. and Bruland, K. W.: Iron-limited diatom growth and $\mathrm{Si}: \mathrm{N}$ uptake ratios in a coastal upwelling regime, Nature, 393, 561-564, 1998.

Hutchins, D. A., DiTullio, G. R., Zhang, Y., and Bruland, K. W.: An iron limitation mosaic in the California upwelling regime, Limnol. Oceanogr., 43, 1037-1054, 1998.

Iglesias-Rodriguez, M. D., Brown, C. W., Doney, S. C., Kleypas, J., Kolber, D., Kolber, Z., Hayes, P. K., and Falkowski, P. G.: Representing key phytoplankton functional groups in ocean carbon cycle models: Coccolithophorids, Global Biogeochem. Cy., 16, 1100, doi:10.1029/2001GB001454, 2002.

Klaas, C. and Archer, D. E.: Association of sinking organic matter with various types of mineral ballast in the deep sea: Implications for the rain ratio, Global Biogeochem. Cy., 16(4), 1116, doi:10.1029/2001GB001765, 2002.

Krauss, W.: The North Atlantic current, J. Geophys. Res., 91, 50615074, 1986.

Kremling, K. and Streu, P.: The behaviour of dissolved Cd, Co, $\mathrm{Zn}$, and $\mathrm{Pb}$ in North Atlantic near-surface waters $\left(30^{\circ} \mathrm{N} / 60^{\circ} \mathrm{W}-\right.$ $\left.60^{\circ} \mathrm{N} / 2^{\circ} \mathrm{W}\right)$, Deep-Sea Res. I, 48, 2541-2567, 2001.

Leblanc, K., Leynaert, A., Fernandez, C., Rimmelin, P., Moutin, T., Raimbault, P., Ras, J., and Queguiner, B.: A seasonal study of diatom dynamics in the North Atlantic during the POMME experiment (2001): Evidence for Si limitation of the spring bloom, J. Geophys. Res., 110, C07S14, doi:10.1029/2004JC002621, 2005.

Leblanc, K., Hare, C. E., Boyd, P. W., Bruland, K. W., Sohst, B., Pickmere, S., Lohan, M. C., Buck, K., Ellwood, M., and Hutchins, D. A.: Fe and Zn effects on the Si cycle and diatom community structure in two contrasting high and low-silicate HNLC areas, Deep-Sea Res. I, 52, 1842-1864, 2005 b.

Lee, P. A., Rudisill, J. R., Neeley, A. R., Hutchins, D. A., Feng, Y., Hare, C. E., Leblanc, K., Rose, J. M., Wilhelm, S. W., Rowe, J. M., and DiTullio, G. R.: Effects of increased $p \mathrm{CO}_{2}$ and temperature on the North Atlantic Spring Bloom. III. Dimethylsulfoniopropionate, Mar. Ecol. Prog Ser., 388, 41-49, 2009.

Llewellyn, C. A. and Mantoura, R. F. C.: Pigment biomarkers and particulate carbon in the upper water column compared to the ocean interior of the northeast Atlantic, Deep Sea Res. I, 43, 1165-1184, 1996.

Lochte, K., Ducklow, H. W., Fasham, M. J. R., and Stienen, C.: Plankton succession and carbon cycling at $47^{\circ} \mathrm{N} 20^{\circ} \mathrm{W}$ during 
the JGOFS North Atlantic bloom experiment, Deep-Sea Res. II, 40, 91-114, 1993.

Lorrain, A., Savoye, N., Chauvaud, L., Paulet, Y.-M., and Naulet, N.: Decarbonation and preservation method for the analysis of organic $\mathrm{C}$ and $\mathrm{N}$ contents and stable isotope ratios of lowcarbonated suspended particulate material, Anal. Chim. Acta, 491, 125-133, 2003.

Mémery, L., Reverdin, G., Paillet, J., and Oschlies, A.: Introduction to the POMME special section: Thermocline ventilation and biogeochemical tracer distribution in the northeast Atlantic Ocean and impact of mesoscale dynamics, J. Geophys. Res., 110, C07S01, doi:10.1029/2005JC002976, 2005.

Moore, C. M., Mills, M. M., Milne, A., Langlois, R., Achterberg, E. P., Lochte, K., Geider, R. J., and La Roche, J.: Iron limits primary productivity during spring bloom development in the central North Atlantic, Glob. Change Biol., 12, 626-634, 2006.

Morel, F. M. M., Milligan, A. J., and Saito, M. A.: Marine bioinorganic chemistry: The role of trace of metals in the oceanic cycles of major nutrients, in: Treatise on geochemistry, edited by: Turekian. K. K. and Holland, H. D., Elsevier Science Ltd, Cambridge, UK, 113-143, 2003.

Moutin, T. and Raimbault, P.: Primary production, carbon export and nutrients availability in western and eastern Mediterranean Sea in early summer 1996 (minos cruise), J. Mar. Sys., 33-34, 273-288, 2002.

Nejstgaard, J. C., Gismervik, I., and Solberg, P. T.: Feeding and reproduction by calanus finmarchicus, and microzooplankton grazing during mesocosm blooms of diatoms and the coccolithophore Emiliania huxleyi, Mar. Ecol. Prog. Ser., 147, 197217, doi:10.3354/MEPS147197, 1997.

Nelson, D. M., Smith, W. O. J., Muench, R. D., Gordon, L. I., Sullivan, C. W., and Husby, D. M.: Particulate matter and nutrient distributions in the ice-edge zone of the Weddell Sea : Relationship to hydrography during late summer, Deep-Sea Res. I, 36, 191-209, 1989.

Otto, L. and Van Aken, H. M.: Surface circulation in the northeast Atlantic as observed with drifters, Deep Sea Res. I, 43, 467-499, 1996.

Passow, U. and Peinert, R.: The role of plankton in particle flux: Two case studies from the northeast Atlantic, Deep-Sea Res. II, 40, 573-585, 1993.

Passow, U. and Alldredge, A. L.: Aggregation of a diatom bloom in a mesocosm: The role of transparent exopolymer particles (TEP), Deep-Sea Res. II, 42, 99-109, 1995.

Passow, U., Shipe, R. F., Murray, A., Pak, D. K., Brzezinski, M. A., and Alldredge, A. L.: Origin of transparent exopolymer particles (TEP) and their role in the sedimentation of particulate matter, Cont. Shelf Res., 21, 327-346, 2001.

Passow, U.: Transparent exopolymer particles (TEP) in aquatic environments, Progr. Oceanogr., 55, 287-333, 2002.

Passow, U.: Switching perspectives: Do mineral fluxes determine particulate organic carbon fluxes or vice versa?, Geochem. Geophy. Geosy., 5, Q04002, doi:10.1029/2003GC000670, 2004.

Passow, U. and De La Rocha, C. L.: Accumulation of mineral ballast on organic aggregates, Global Biogeochem. Cy., 20, GB1013, doi:10.1029/2005GB002579, 2006.

Ras, J., Claustre, H., and Uitz, J.: Spatial variability of phytoplankton pigment distributions in the Subtropical South Pacific Ocean: comparison between in situ and predicted data, Biogeosciences,
5, 353-369, 2008, http://www.biogeosciences.net/5/353/2008/.

Riebesell, U., Reigstad, M., Wassmann, P., Noji, T., and Passow, U.: On the trophic fate of Phaeocystis pouchetii (Hariot): VI. Significance of Phaeocystis-derived mucus for vertical flux, Neth. J. Sea Res., 33, 193-203, 1995.

Rose, J. M., Feng, Y., Gobler, C. J., Gutierrez, R., Hare, C. E., Leblanc, K., and Hutchins, D. A.: The effects of increased $\mathrm{pCO}_{2}$ and temperature on the North Atlantic Spring Bloom. II. Microzooplankton abundance and grazing, Mar. Ecol. Prog Ser., 388, 27-40, 2009.

Robinson, A. R., McGillicuddy, D. J., Calman, J., Ducklow, H. W., Fasham, M. J. R., Hoge, F. E., Leslie, W. G., McCarthy, J. J., Podewski, S., Porter, D. L., Saure, G., and Yoder, J. A.: Mesoscale and upper ocean variabilities during the 1989 JGOFS bloom study, Deep Sea Res. II, 40, 9-35, 1993.

Rowe, J. M., Saxton, M. A., Cottrell, M. T., DeBruyn, J. M., Berg, G. M., Kirchman, D. L., Hutchins, D. A., and Wilhelm, S. W.: Constraints on viral production in the Sargasso Sea and North Atlantic, Aquat. Microb. Ecol., 52, 233-244, doi:10.3354/AME01231, 2008.

Sarmiento, J. L. and Gruber, N.: Ocean biogeochemical dynamics, Princeton University Press 526 pp., 2006.

Savidge, G., Boyd, P., Pomroy, A., Harbour, D., and Joint, I.: Phytoplankton production and biomass estimates in the northeast Atlantic Ocean, May-June 1990, Deep-Sea Res. I, 42, 599-617, 1995.

Savidge, G. and Williams, P. J. 1. B.: The PRIME 1996 cruise: An overview, Deep-Sea Res. II, 48, 687-704, 2001.

Schoemann, V., Becquevort, S., Stefels, J., Rousseau, V., and Lancelot, C.: Phaeocystis blooms in the global ocean and their controlling mechanisms: A review, J. Sea Res., 53, 43-66, 2005.

Sieracki, M. E., Verity, P. G., and Stoecker, D. K.: Plankton community response to sequential silicate and nitrate depletion during the 1989 North Atlantic spring bloom, Deep-Sea Res. II, 40, 213-225, 1993.

Solorzano, L. and Sharp, J. H.: Determination of total dissolved nitrogen in natural waters, Limnol. Oceanogr., 25, 754-758, 1980.

Sunda, W. G. and Huntsman, S. A.: Iron uptake and growth limitation in oceanic and coastal phytoplankton, Mar. Chem., 50, 189-206, 1995a.

Sunda, W. G. and Huntsman, S. A.: Cobalt and Zinc interreplacement in marine phytoplankton: Biological and geochemical implications, Limnol. Oceanogr., 40, 1404-1417, 1995 b.

Takeda, S.: Influence of iron availability on nutrient consumption ratio of diatoms in oceanic waters, Nature, 393, 774-777, 1998.

Tang, D. and Morel, F. M. M.: Distinguishing between cellular and fe-oxide-associated trace elements in phytoplankton, Mar. Chem., 98, 18-30, 2006.

Taylor, A. H., Harbour, D. S., Harris, R. P., Burkill, P. H., and Edwards, E. S.: Seasonal succession in the pelagic ecosystem of the North Atlantic and the utilization of nitrogen, J. Plankton Res., 15, 875-891, 1993.

Tovar-Sanchez, A., Sañudo-Wilhelmy, S. A., Garcia-Vargas, M., Weaver, R. S., Popels, L. C., and Hutchins, D. A.: A trace metal clean reagent to remove surface-bound iron from marine phytoplankton, Mar. Chem., 82, 91-99, 2003.

Uitz, J., Claustre, H., Morel, A., and Hooker, S. B.: Vertical distribution of phytoplankton communities in open ocean: An as- 
sessment based on surface chlorophyll, J. Geophys. Res., 111, C08005, doi:08010.01029/02005JC003207, 2006.

Watson, A. J., Robinson, C., Robinson, J. E., le B. Williams, P. J., and Fasham, M. J. R.: Spatial variability in the sink for atmospheric carbon dioxide in the North Atlantic, Nature, 350, 50-53, 1991.
Williams, R. and Claustre, H.: Photosynthetic pigments as biomarkers of phytoplankton populations and processes involved in the transformation of particulate organic matter at the Biotrans site $\left(47^{\circ} \mathrm{N}, 20^{\circ} \mathrm{W}\right)$, Deep-Sea Res. I, 38, 347-355, 1991. 